\title{
Nodulation Induces Systemic Resistance of Medicago truncatula and Pisum sativum Against Erysiphe pisi and Primes for Powdery Mildew-Triggered Salicylic Acid Accumulation
}

\author{
Lara Smigielski, ${ }^{1}$ Eva-Maria Laubach, ${ }^{1}$ Lina Pesch, ${ }^{1}$ Joanna Marie Leyva Glock, ${ }^{1}$ Frank Albrecht, ${ }^{2}$ \\ Alan Slusarenko, ${ }^{2}$ Ralph Panstruga, ${ }^{1}$ and Hannah Kuhn ${ }^{1,+}$ \\ ${ }^{1}$ Institute for Biology I, Unit of Plant Molecular Cell Biology, RWTH Aachen University, Worringerweg 1, 52056 Aachen, \\ Germany \\ ${ }^{2}$ Institute for Biology III, Department of Plant Physiology, RWTH Aachen University
}

Accepted 26 April 2019.

\begin{abstract}
Plants encounter beneficial and detrimental microorganisms both above- and belowground and the health status of the plant depends on the composition of this pan-microbiome. Beneficial microorganisms contribute to plant nutrition or systemically or locally protect plants against pathogens, thus facilitating adaptation to a variety of environments. Induced systemic resistance, caused by root-associated microbes, manifests as aboveground resistance against necrotrophic pathogens and is mediated by jasmonic acid/ethylene-dependent signaling. By contrast, systemic acquired resistance relies on salicylic acid (SA) signaling and confers resistance against secondary infection by (hemi)biotrophic pathogens. To investigate whether symbiotic rhizobia that are ubiquitously found in natural ecosystems are able to modulate resistance against biotrophs, we tested the impact of preestablished nodulation of Medicago truncatula and pea (Pisum sativum) plants against infection by the powdery mildew fungus Erysiphe pisi. We found that root symbiosis interfered with fungal penetration of $M$. truncatula and reduced asexual spore formation on pea leaves independently of symbiotic nitrogen fixation. Improved resistance of nodulated plants correlated with elevated levels of free SA and SA-dependent marker gene expression upon powdery mildew infection. Our results suggest
\end{abstract}

\section{Smigielski and E.-M. Laubach contributed equally to this work.}

Current address of L. Smigielski: Department of Plant and Environmental Sciences, Copenhagen Plant Science Center (CPSC), University of Copenhagen, Thorvaldsensvej 40, 1871 Frederiksberg C., Denmark.

Current address of L. Pesch: Botanical Institute, Cologne Biocenter, University of Cologne, Zülpicher Straße 47b, 50674 Cologne, Germany.

${ }^{\dagger}$ Corresponding author: H. Kuhn; hannah.kuhn@rwth-aachen.de

Funding: We thank RWTH Aachen University for funding H. Kuhn with an RWTH Start-Up grant and R. Panstruga with a Seed Fund grant in the context of the Excellence Initiative of the German federal and state governments.

*The $\boldsymbol{e}$-Xtra logo stands for "electronic extra" and indicates that one supplementary table and four supplementary figures are published online.

The author(s) declare no conflict of interest.

๑) 2019 The American Phytopathological Society that nodulation primes the plants systemically for $E$. pisi-triggered $\mathrm{SA}$ accumulation and defense gene expression, resulting in increased resistance.

Keywords: bacteria-plant symbiosis, ethylene, fungus-plant interactions, hormones, induced systemic resistance, jasmonic acid, nodulation, pathogens, plant antifungal responses, powdery mildew, rhizobium-legume symbiosis, salicylic acid, symbiosis

In their natural environment, plants interact with a plethora of microbes both above- and belowground. The composition of the plant microbiome ultimately shapes the plant's ability to adapt to prevailing conditions (Müller et al. 2016). Beneficial belowground interactions - for example with plant growth-promoting rhizobacteria (PGPR) or plant growth-promoting fungi (PGPF), as well as root endosymbionts such as rhizobia and arbuscular mycorrhizal fungi-help the plant gain access to nutrients and grow on poor or contaminated substrates (e.g., salt or heavy metals) (Miransari 2010). Some beneficial microbes enhance the capability of plants to defend themselves against invaders (Beneduzi et al. 2012; Gray and Smith 2005; Pieterse et al. 2014). Root-interacting microbes can enhance resistance either directly via competition with pathogens or the secretion of antimicrobial substances, or indirectly via induced systemic resistance (ISR) (Müller et al. 2016, Pieterse et al. 2014). In contrast to ISR, which is mediated by beneficial root interactions, a primary local infection by a pathogen can increase resistance to a secondary pathogen attack in distal tissue, a phenomenon named systemic acquired resistance (SAR) (Fu and Dong 2013; Pieterse et al. 2014). Both ISR and SAR rely on phytohormones. However, whereas ISR largely depends on jasmonic acid (JA) and ethylene (ET) signaling (Pieterse et al. 1998), SAR is salicylic acid (SA) dependent (Vernooij et al. 1994). It has been shown in Arabidopsis thaliana that SA-dependent SAR mediates defense against biotrophic pathogens, whereas JA- or ETdependent ISR is effective against necrotrophic pathogens and herbivores (Glazebrook 2005; Loake and Grant 2007; Pieterse et al. 2014; Pozo and Azcón-Aguilar 2007; Thomma et al. 2001; Ton et al. 2002; van Dam and Heil 2011; Van Loon and Bakker 2006). ISR has been reported to be effective against a plethora of root- or shoot-infecting bacteria and filamentous pathogens in monocots and dicots, including important crops such as barley (Hordeum 
vulgare), maize (Zea mays), tomato (Solanum lycopersicum), French bean (Phaseolus vulgaris), cucumber (Cucumis sativus), tobacco (Nicotiana tabacum), and grapevine (Vitis vinifera) (Alabouvette et al. 2009; Cameron et al. 2013; Walters et al. 2013). ISR is induced by PGPR such as Pseudomonas, Serratia, and Bacillus strains (De Vleesschauwer and Höfte 2009, Kloepper et al. 2004), as well as nonpathogenic Fusarium spp., Trichoderma spp., and Piriformospora indica (Alabouvette et al. 2009; Franken 2012; Shoresh et al. 2010) and arbuscular mycorrhizal fungi (Cameron et al. 2013; Jung et al. 2012). These organisms are regarded as significant biocontrol agents (Beneduzi et al. 2012).

Both ISR and SAR are associated with "priming"; that is, the ability of a plant, after a conditioning treatment, to respond more rapidly and strongly in terms of cellular defense reactions upon challenge by a pathogen than nonconditioned plants (Conrath et al. 2006; Mauch-Mani et al. 2017; Ton et al. 2009). Systemic defense priming requires either functional SA or JA/ET pathways depending on whether SAR or ISR, respectively, are conditioned (Conrath et al. 2015, Pieterse et al. 2014). SAR coincides with the accumulation of SA after a primary infection (Gao et al. 2015; Malamy et al. 1990; Návarová et al. 2012) or upon a secondary challenge (Jung et al. 2009), whereas PGPR-induced ISR priming in Arabidopsis seems to be based on an enhanced sensitivity to JA and ET rather than on an increase in their abundance per se (Pieterse et al. 2000, 2014; van Wees et al. 1999). In either case, in Arabidopsis, defense priming involves the challenge-induced expression of genes that potentially contribute to defense execution. In SAR, these are SA signaling-induced pathogenesisrelated $(P R)$ genes (Malamy et al. 1990; Ryals et al. 1996; Van Loon and Bakker 2006), while ISR primes for expression of distinct JA- or ET-responsive genes (Hoffland et al. 1995; Pieterse et al. 1998, 2014; Ryals et al. 1996; van Wees et al. 1999; Verhagen et al. 2004).

Root-nodulating rhizobia, which are occasionally referred to as intracellular PGPR (Gray and Smith 2005), are widely present in natural ecosystems and undergo mutualistic interactions with roots of legumes, many of which are important crop plants; for example, pea (Pisum sativum), bean (Phaseolus vulgaris), lentil (Lens culinaris), and soybean (Glycine max); or forage plants such as alfalfa (Medicago sativa). In the symbiotic relationship with the host, the bacteria are enclosed in root nodules, where they differentiate into intracellular host membrane-enclosed bacteroids and fix atmospheric nitrogen that becomes available to the plant as ammonium (Desbrosses and Stougaard 2011). Thus, they promote legume growth by enabling nitrogen acquisition under limiting conditions, which makes rhizobia valuable agents for sustainable agriculture (Bohlool et al. 1992). Similar to other beneficial or detrimental plant-infecting microbes, rhizobia facilitate initial colonization by suppressing microbe-associated molecular pattern (MAMP)-triggered plant defense (Zamioudis and Pieterse 2012). Furthermore, similar to arbuscular mycorrhizal fungi, rhizobia repress SA-dependent defense in the roots that would otherwise prevent infection (Foo et al. 2014; Gutjahr and Paszkowski 2009). This suppression requires secretion of bacterial lipo-chitooligosaccharides (LCOs) designated as nod factors, which bind to specific plant receptors and initiate the host's symbiotic program (Martínez-Abarca et al. 1998). Although ISR has been studied extensively with classical PGPR and PGPF, little is known about effects of rhizobial symbiosis on systemic plant defense. Most reports on rhizobial control of plant pathogens tested a direct intermicrobial effect on soilborne root-infecting microbes, rather than on induced resistance (Buonassisi et al. 1986; Dakora 2003; EhteshamulHaque and Ghaffar 1993; Tu 1978, 1979). However, arbuscular mycorrhiza, which share components of a common plant symbiosis pathway with nodulation, trigger systemic priming of defense responses effective against necrotrophic and hemibiotrophic pathogens (Fritz et al. 2006; Lingua et al. 2002; Liu et al. 2007). The plant symbiosis pathway is triggered by perception of bacterial nod factors or fungal (Myc-) LCOs similar to fungal chitooligosaccharides that elicit MAMP-triggered immune signaling (Zipfel and Oldroyd 2017). Interestingly, PGPR-mediated ISR is linked to the perception of MAMPs or avirulence-like protein effectors (Burketova et al. 2015; De Vleesschauwer and Höfte 2009; Shoresh et al. 2010). Rhizobial nod factors have been reported to induce resistance against pathogens. For example, application of nod factors to soybean roots limited colony size of Microsphaera diffusa powdery mildew on leaves in a dosedependent manner (Duzan et al. 2005). Notably, powdery mildew fungi are biotrophic pathogens that are strongly susceptible to SA-mediated defense, resulting in reduced colony expansion and asexual reproduction (Chandran et al. 2009; Zimmerli et al. 2004). Accordingly, Arabidopsis mutants, or transgenic plants impaired in SA biosynthesis, accumulation, or signaling, display increased susceptibility to adapted powdery mildews (Chandran et al. 2009; Dewdney et al. 2000; Ederli et al. 2015). By contrast, JA-mediated defense is either suppressed or fails to be elicited by adapted powdery mildews (Antico et al. 2012; Kuhn et al. 2016). However, Arabidopsis root colonization with the PGPF Piriformospora indica reduces powdery mildew asexual spore formation (conidiation) in a JA-dependent manner (Stein et al. 2008), and JA-induced defense responses are effective against adapted powdery mildew fungi when triggered ectopically. For example, by exogenous application of JA, regardless of the biotrophic nature of the subsequent challenge (Ellis et al. 2002a and b; Zimmerli et al. 2004). By contrast, arbuscular mycorrhiza elicited ISR, which is mostly but not exclusively linked to JA/ET signaling (Cameron et al. 2013), was found to be associated with enhanced susceptibility to biotrophic powdery mildews in barley (Gernns et al. 2001; Sonnemann et al. 2005). In conclusion, only a few reports exist on the effectiveness of ISR against biotrophic powdery mildews (Panstruga and Kuhn 2019), and even fewer data are available on nodulation-related ISR, despite the agronomical importance of legumes. In the case of infected pea, powdery mildew can result in yield losses of 25 to 50\% (Maharjan et al. 2015). The elicitation of systemic resistance against biotrophic powdery mildews by nod factors applied to roots suggests that ISR might be triggered by rhizobia (Duzan et al. 2005). Whether or not nodulation mediates a systemic effect similar to arbuscular mycorrhiza-induced ISR, and whether SA or JA signaling might be involved in the defense signaling initiated by rhizobia, is not known. The most obvious benefit to the plant of nodulation is the uptake of nitrogen via the nitrogenfixing microsymbiont (Downie 2014). This improves the nutritional status and fitness of the plant (Kaschuk et al. 2010). Activation of plant defenses by pathogens coincides with high metabolic costs to the plant and limited access to nitrogen can impair defense (Baldwin et al. 1998; van Dam and Baldwin 1998). Accordingly, in addition to systemic resistance effects, nodulated plants might be expected to be able to mount a more robust defense response than plants with inadequate nitrogen due to a growth-defense tradeoff impacting fitness (Huot et al. 2014).

Here, we investigated the impact of an established nodule symbiosis on susceptibility of two distinct legumes, Medicago truncatula and pea, against the powdery mildew fungus Erysiphe pisi. We show that nodulation quantitatively increases resistance and primes $E$. pisi-triggered accumulation of free SA in leaves. Elevated SA concentrations correlates with enhanced 
transcript abundance of SA-responsive genes in leaves, suggesting that SA signaling contributes to powdery mildew resistance and pointing toward an SAR-like mechanism acting from the root to the shoot.

\section{RESULTS}

\section{Preestablished nodulation enhances powdery mildew resistance of $M$. truncatula and Pisum sativum.}

To investigate whether nodulation of $M$. truncatula by Sinorhizobium meliloti influences the susceptibility of the host independently of a symbiotic nitrogen nutritional effect, we inoculated 3 -week-old nodulated plants and nitrate-fertilized plants with the adapted powdery mildew fungus E. pisi (Fig. 1; Supplementary Fig. S1). Because the widely used $M$. truncatula inbred line 'Jemalong A17' is resistant to $E$. pisi, we used the highly susceptible line DZA315.16 (Foster-Hartnett et al. 2007). Without nodulation or nitrate supplementation, seedlings made poor growth and yellowed rapidly. Therefore, nonnodulated nonnitrogen-supplemented plants were not used in experiments. By contrast, plants supplied with nitrate did not differ statistically significantly from nodulated plants in their shoot height or dry and wet weight. They further had no statistically significant different nitrogen levels at 1 (3-week-old plants) and 7 (4-week-old plants) days post-fungal inoculation (dpi) (Fig. 1A). Nodule numbers of powdery mildew-inoculated and noninoculated plants were similar, showing that powdery mildew infection did not affect nodule formation (Fig. 1B). Interestingly, despite comparable nitrogen contents, preestablished nodulation of $M$. truncatula resulted in a reduced degree of epidermal
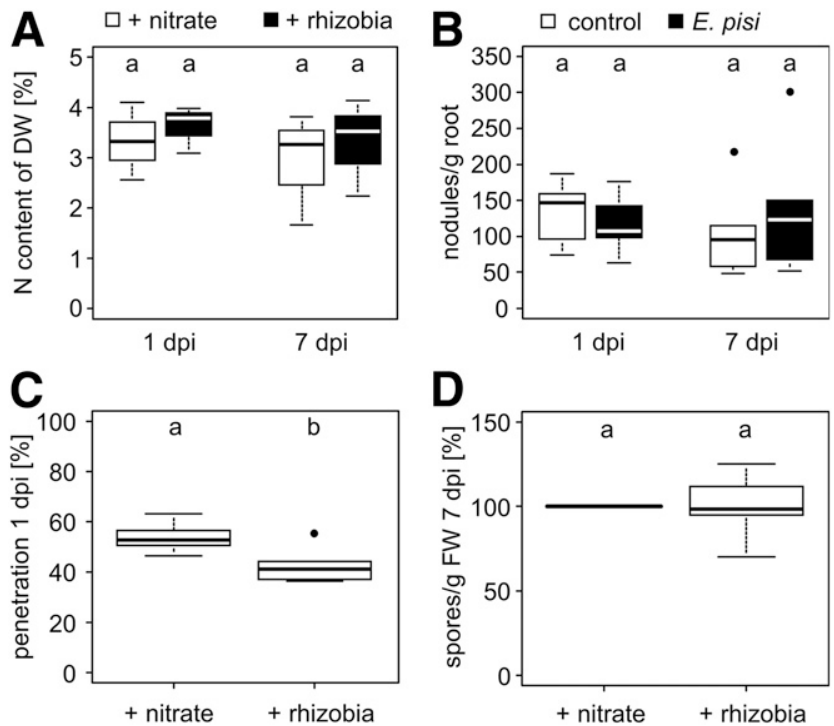

Fig. 1. Nodulation contributes to penetration resistance of Medicago truncatula against Erysiphe pisi. Three-week-old $M$. truncatula plants that had been nodulated with Sinorhizobium meliloti or supplemented with 250 $\mathrm{ml}$ of $7.5 \mathrm{mM} \mathrm{KNO}_{3}$ per nine seedlings as 2-day-old seedlings were either inoculated with $E$. pisi or kept as a control. A, Nitrogen content of dry weight (DW) of leaves was determined by gas chromatography. B, Abundance of nodules per root weight was evaluated after staining for rhizobial $\beta$-glucuronidase activity. $\mathbf{C}$, Penetration success of $E$. pisi was scored as percentage of successful penetration events, visible by formation of secondary hyphae. D, Fungal spore formation per leaf fresh weight (FW) was assessed by removal of conidia with water and counting in a Neubauer improved chamber. Spore numbers of nitrate-supplemented controls were set to $100 \%$. Data labeled with the same letters are not statistically significantly different $(P \leq 0.05$; tested by one-way analysis of variance and Tukey's honestly significant difference post hoc test (A, B, and C, $n=$ six independent experiments with $\geq 18$ plants per time point and treatment) or by Wilcoxon rank sum test $(\mathrm{D}, n=$ three independent experiments with $\geq 18$ plants per time point and treatment); dpi = days postinoculation with $E$. pisi. penetration by $E$. pisi. The average penetration success at $1 \mathrm{dpi}$ was reduced statistically significantly $(P<0.05)$ by approximately $10 \%$ from $54 \%$ on control plants to $43 \%$ on nodulated plants (Fig. 1C). By contrast, the degree of sporulation at $7 \mathrm{dpi}$ was the same for both treatments (Fig. 1D). This result indicates that nodulation of $M$. truncatula increases penetration resistance against $E$. pisi but does not influence postpenetration resistance.

To test whether an additional legume would behave correspondingly, Rhizobium leguminosarum-mediated nodulation of 2- to 3-week-old pea plants was also tested for possible effects on E. pisi infection. Nonnodulated pea plants supplemented with $5 \mathrm{mM}$ nitrate did not differ in their appearance from nodulated plants. Furthermore, the leaf nitrogen content between both groups was not statistically significantly different after 1 or 7 dpi with E. pisi (Fig. 2A). Likewise, abundance of nodules was not influenced by inoculation with the fungus (Fig. 2B). However, in contrast to M. truncatula, nodulation did not affect fungal penetration at $1 \mathrm{dpi}$ (Fig. 2C) but did result in a statistically significant reduction $(P<0.05)$ in sporulation at $7 \mathrm{dpi}$ (Fig. 2D). Taken together, these data point to an impact of a preestablished nodulation on early prepenetration $(M$. truncatula) or late postpenetration (pea) resistance against $E$. pisi, which is uncoupled from the benefits of symbiotic nitrogen supply.

\section{Nodulation of $M$. truncatula does not alter susceptibility to Xanthomonas campestris pv. alfalfae.}

M. truncatula is a host for the hemibiotrophic bacterial leaf pathogen Xanthomonas campestris pv. alfalfae (Liu et al. 2007) that causes leaf spot disease of alfalfa (Esnault et al. 1993;
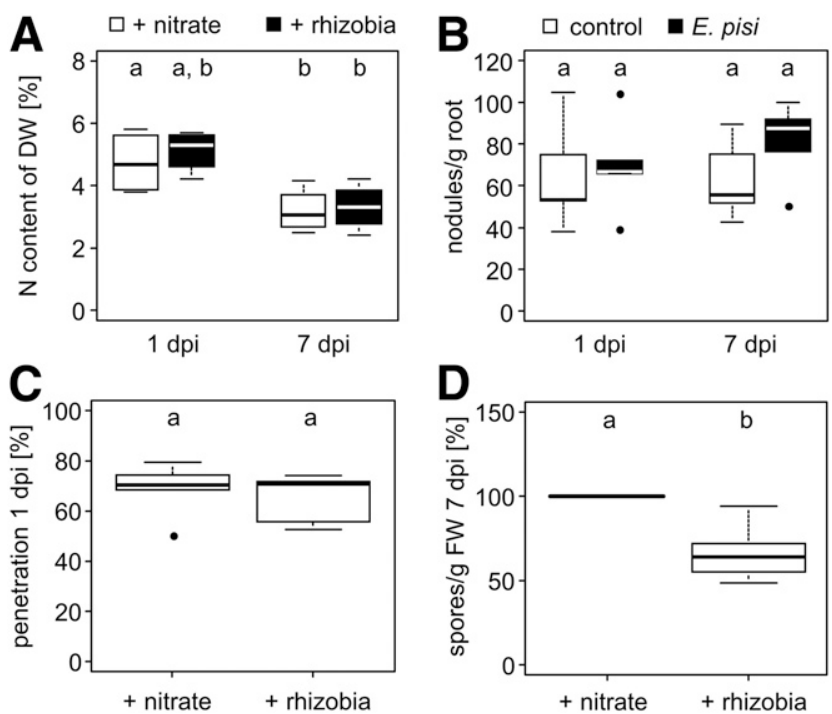

Fig. 2. Nodulation contributes to postpenetration resistance of pea against Erysiphe pisi. Two-week-old pea plants that had been nodulated with Rhizobium leguminosarum or supplemented with $250 \mathrm{ml}$ of $5 \mathrm{mM} \mathrm{KNO}_{3}$ per four germinating seeds were either inoculated with $E$. pisi or kept as a control. A, Nitrogen content of weight (DW) of leaves was determined by gas chromatography. B, Abundance of nodules per root weight was evaluated after staining for rhizobial $\beta$-glucuronidase activity. $\mathbf{C}$, Penetration success of $E$. pisi was scored as percentage of successful penetration events visible by formation of secondary hyphae. D, Fungal spore formation per leaf fresh weight (FW) was assessed by removal of conidia with water and counting in a Neubauer improved chamber. Spore numbers of nitrate-supplemented controls were set to $100 \%$. Data labeled with the same letters are not statistically significantly different $(P \leq 0.05$; tested by one-way analysis of variance and Tukey's honestly significant difference post hoc test (A, B, and $\mathrm{C}, n=5$ independent experiments with $\geq 9$ plants per time point and treatment) or by Wilcoxon rank sum test $(\mathrm{D}, n=5$ independent experiments with $\geq 9$ plants per time point and treatment); dpi = days postinoculation with E. pisi. 
Riker et al. 1935). To test whether nodulation might also influence this interaction with a hemibiotrophic pathogen, we sprayinoculated nitrate-fertilized or S. meliloti-nodulated plants with $X$. campestris pv. alfalfae and evaluated bacterial multiplication and nodule abundance at 3 and 7 dpi (Supplementary Fig. S2). We observed the appearance of yellowish (chlorotic) leaf areas and necrotic spots at $7 \mathrm{dpi}$, indicating successful infection of $M$. truncatula. X. campestris pv. alfalfae infection did not affect the extent of nodule formation. However, in contrast to powdery mildew infection, nodulation of $M$. truncatula affected neither bacterial infection nor multiplication and had no strong impact on the severity of disease symptoms.

\section{Transcripts of SA-responsive genes accumulate differentially after $E$. pisi inoculation of nodulated $M$. truncatula plants.}

Increased resistances of plants against pathogen infection in systemic tissues can be mediated by SAR or ISR. Although SAR mostly depends on SA, ISR often requires the action of JA or ET (Pieterse et al. 1998; Vernooij et al. 1994). To investigate whether SAR or ISR might be involved in the enhanced powdery mildew resistance shown by nodulated plants, we examined steady-state transcript levels of SA- or JA-responsive genes, of which many are well characterized in Arabidopsis. To identify SA- and JA-responsive genes in M. truncatula, we mined the
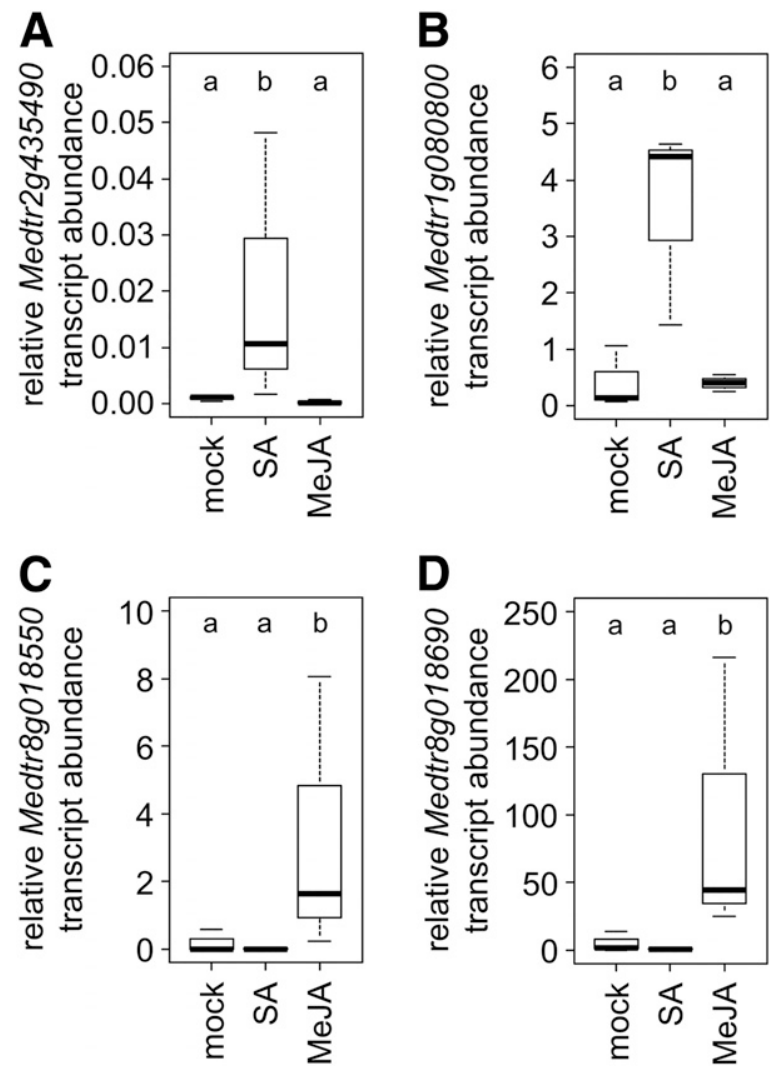

Fig. 3. Effects of salicylic acid (SA) and methyl jasmonate (MeJA) on the transcript abundance of Medicago truncatula candidate reporter genes. Three-week-old M. truncatula plants were sprayed with either $1 \mathrm{mM}$ MeJA, $10 \mathrm{mM} \mathrm{SA}$, or water as a control and transcript abundance of $\mathbf{A}$, Medtr2g435490; B, Medtrlg080800; C, Medtr8g018550; and D, Medtr8g018690 in leaves was determined at $12 \mathrm{~h}$ after the treatment via quantitative reverse-transcription PCR analysis relative to the reference gene MtTEFl $\alpha$ (Medtr6g021800). Data labeled with the same letters are not statistically significantly different $(P \leq 0.05$; tested by one-way analysis of variance and Tukey's honestly significant difference post hoc test); $n=3$ independent experiments with $\geq 6$ plants per treatment. genome for candidates with high protein sequence similarity to well-established hormone-responsive genes from Arabidopsis. One of the best-characterized SA-responsive genes in Arabidopsis is AtPR-1, while AtPR-4 is described as a reporter gene for JA or ET signaling (Lorenzo et al. 2004; Potter et al. 1993; Van Loon and Bakker 2006; Vernooij et al. 1994). Medtr2g435490 (58\% amino acid identity) and Medtrlg080800 (71\% amino acid identity) were identified as potential homologs of AtPR-1 and $A t P R-4$, respectively, in the Mt3.5v5 genome assembly (Supplementary Fig. S3). Please note that, in the most recent genome version (Mt4.0v2), other M. truncatula proteins show higher amino acid identities to AtPR-1 and AtPR-4. To investigate the suitability of the selected candidates as SA or JA reporter genes, we performed hormonal treatments and tested for altered mRNA levels.

Spraying of M. truncatula leaves with $10 \mathrm{mM}$ SA statistically significantly increased transcript abundance of the AtPR-1 homolog Medtr 29435490 by $13 \mathrm{~h}$ after treatment (approximately ninefold, considering the medians) (Fig. 3A). Surprisingly, the mRNA abundance of the AtPR-4 relative Medtrlg080800 did not increase in response to treatment with $1 \mathrm{mM}$ methyl jasmonate (MeJA) but accumulated statistically significantly after SA treatment (approximately 33-fold, considering the medians) (Fig. 3B). This finding suggests that the genes are regulated differently in Arabidopsis and M. truncatula and that, regardless of whether or not the candidates are the functional orthologs of AtPR-1 and AtPR-4, Medtrlg080800, in addition to Medtr2g435490, can serve as a marker gene for SA signaling. In an alternative approach, the Genevestigator database (Hruz et al. 2008) was mined for genes with JA-responsive expression. Medtr8g018550 and Medtr 8018690 showed a strong transcript accumulation in root-derived suspension-cultured cells treated with MeJA (Naoumkina et al. 2007) and were selected as JA-responsive candidate genes. A protein BLAST search revealed their closest homologs in Arabidopsis as the lipoxygenase (LOX) AtLOX1 (Medtr8g018550; 56\% amino acid identity and Medtr8g018690; $55 \%$ amino acid identity). Certain LOXs contribute to the biosynthesis of JA and other defense-related compounds (Wasternack and Hause 2013), and many of the respective LOX genes are induced by JA in Arabidopsis (Wasternack 2007). However, AtLOX1 encodes a 9-LOX that is not involved in JA biosynthesis in Arabidopsis but is induced after inoculation with Pseudomonas syringae pv. tomato DC3000 and contributes to local and systemic defense against bacterial pathogens (Vicente et al. 2012) and to JA signaling during Fusarium graminearum infection (Nalam et al. 2015). The mRNA of both $M$. truncatula genes accumulated statistically significantly after treatment of leaves with $1 \mathrm{mM}$ MeJA in contrast to mock-treated controls (approximately 27-fold for Medtr8g018550 and approximately 3,008-fold for Medtr8g018690, considering the medians) (Fig. 3C and D).

To investigate whether nodulation might affect transcript levels of SA- and MeJA-responsive genes in leaves of M. truncatula plants upon infection, we inoculated 3-week-old nodulated or nitrate-supplemented plants with $E$. pisi as described above and measured transcript accumulation at 1 and 7 dpi (Fig. 4). Although mRNA abundance of the JA-responsive genes Medtr8g018550 and Medtr8g018690 did not alter consistently in any of the treatments (Fig. 4C and D), E. pisi inoculation induced transcript accumulation of the SAresponsive genes Medtr2g435490 and Medtrlg080800 at 7 dpi (Fig. 4A and B). The accumulation of the Medtr2g435490 and Medtrlg080800 transcripts in leaves of nodulated plants was slightly, although not statistically significantly, higher than in nonnodulated plants at $7 \mathrm{dpi}$ (Fig. 4A and B). The mRNA of both genes also accumulated marginally at 1 dpi after E. pisi, inoculation in nodulated compared with nonnodulated plants but 
this effect was less pronounced as at $7 \mathrm{dpi}$ and not statistically significant (Fig. 4A and B).

Consistent with our findings, Foster-Hartnett et al. (2007) and Samac et al. (2011) observed E. pisi-induced transcript accumulation in M. truncatula of the PR-4-like Medtr1g080800 (synonymous with the J. Craig Venter Institute [formerly TIGR] tentative consensus IDs TC125088 and TC101688), together with $P R$-10-like genes and members of the chalcone synthase $(\mathrm{CHS})$ gene family. CHSs are involved in phyenylpropanoid metabolism contributing to biosynthesis of the isoflavonoid phytoalexin medicarpin in Medicago spp. (Dixon et al. 2002; Paiva et al. 1994). Furthermore, M. truncatula CHS genes and other phenylpropanoid, flavonoid, and isoflavonoid biosynthesis pathway genes were induced upon infection with the Asian soybean rust Phakopsora pachyrhizi; and the isoflavonoid derivative medicarpin, which increases after $P$. pachyrhizi inoculation, contributed to nonhost resistance against this biotrophic fungus (Ishiga et al. 2015). To test whether E. pisi-triggered gene expression is enhanced by nodulation, we investigated the transcript accumulation of canonical MtPR-10 and $M t C H S$ genes in our samples. We designed oligonucleotide primer pairs that match multiple isoforms within each gene family (oligonucleotides used for quantitative PCR [qPCR] are listed in Supplementary Table S1). Although the transcript abundance of the respective set of genes increased upon E. pisi inoculation (Supplementary Fig. S4), this increase was only statistically significant for the $M t C H S$ genes in leaves of
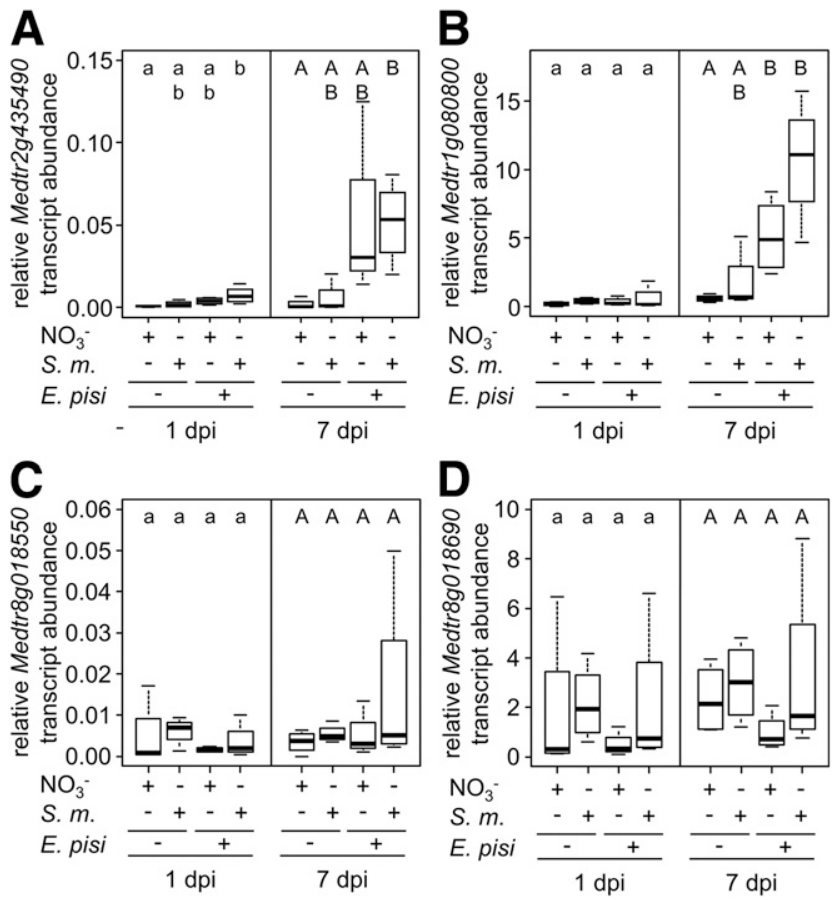

Fig. 4. Nodulation promotes Erysiphe pisi-triggered transcript accumulation of salicylic acid (SA)- but not of jasmonic acid (JA)-responsive Medicago truncatula genes. Three-week-old $M$. truncatula plants that had been nodulated with Sinorhizobium meliloti or supplemented with $7.5 \mathrm{mM}$ $\mathrm{KNO}_{3}$ as 2-day-old seedlings were either inoculated with E. pisi or kept as a control. Transcript abundance of A, Medtr2g435490; B, Medtr1g080800; C, Medtr8g018550; and D, Medtr8g018690 in leaves was determined at 1 and 7 days postinoculation (dpi) with $E$. pisi via quantitative reverse-transcription PCR analysis relative to the reference gene MtTEF1 $\alpha$ (Medtr6g021800). Data labeled with the same letters are not statistically significantly different $(P \leq 0.05$; tested by one-way analysis of variance and Tukey's honestly significant difference post hoc test); $n=4$ independent experiments with $\geq 18$ plants per time point and treatment and $S . m$. = Sinorhizobium meliloti.
S. meliloti at $7 \mathrm{dpi}$. Investigation of a possible phytohormone dependency of the transcript elevation, as observed for Medtrlg080800 and Medtr2g435490, suggested an SArelated induction of the $M t P R-10$ genes and a JA-triggered repression of the $M t C H S$ genes, which was, however, in both cases, not statistically significant.

\section{Enhanced levels of free SA correlate} with increased resistance of nodulated plants.

The elevated abundance of SA-responsive transcripts after E. pisi inoculation in M. truncatula leaves suggested a gain of SA signaling, which was possibly further intensified by nodulation. To test whether the observed increase in transcript abundance of SA marker genes correlates with increased SA content, we measured SA levels in the leaves of nodulated and nonnodulated pea and $M$. truncatula. E. pisi inoculation of $M$. truncatula increased the concentration of free SA statistically significantly in leaves of nodulated plants at both 1 and 7 dpi whereas, in nonnodulated plants, an intermediate, not statistically significant increase was only observed at the later time point (Fig. 5A). This result correlates well with the observed greater resistance of nodulated plants at 1 dpi compared with nonnodulated plants whereas, at $7 \mathrm{dpi}$, the nitrogen-supplemented plants appeared similarly susceptible (Fig. 1C to D). These findings suggest that nodulation allows a faster accumulation of free SA after powdery mildew challenge, which is consistent with the hypothesis that nodulated plants are primed for SA accumulation.

Free SA concentrations were determined in leaves of nodulated and nonnodulated pea plants inoculated with E. pisi or not, respectively. Considerably higher amounts of SA were measured in pea $(1,200$ to $11,900 \mathrm{ng} / \mathrm{g}$ fresh weight $[\mathrm{FW}])$ than in M. truncatula (20 to $840 \mathrm{ng} / \mathrm{g} \mathrm{FW}$ ) (Fig. 5B). In pea, a statistically significant increase in SA levels was only observed for nodulated plants at $7 \mathrm{dpi}$. Again, this outcome correlates well with the observation of greater resistance of nodulated compared with nitrogen-supplemented plants only at $7 \mathrm{dpi}$ (Figs. 5B and 2D) but not at $1 \mathrm{dpi}$, where nodulation did not appear to affect resistance (Fig. 2C). In conclusion, nodulation of pea and M. truncatula primed the plants for E. pisi-triggered
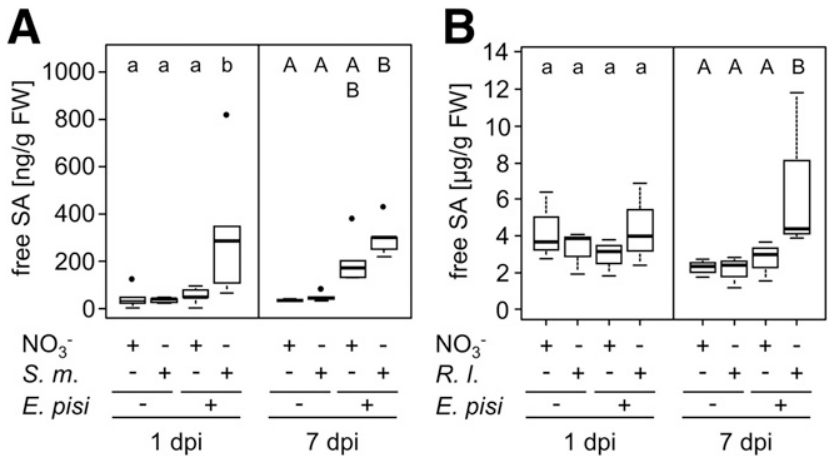

Fig. 5. Nodulation primes for Erysiphe pisi-triggered salicylic acid (SA) accumulation in Medicago truncatula and pea leaves. A, The 3-week-old nodulated M. truncatula plants; B, 2-week-old nodulated pea plants; or the respective $\mathrm{KNO}_{3}$-supplemented control plants were either inoculated with E. pisi or kept as a control. Free SA was extracted from leaves and analyzed by high-performance liquid chromatography at 1 and 7 days postinoculation (dpi). Data labeled with the same letters are not statistically significantly different $(P \leq 0.05$; tested by one-way analysis of variance and Tukey's honestly significant difference post hoc test); $n=5$ (A) and 3 (B) independent experiments with $\geq 18$ (M. truncatula) or 9 (pea) plants per time point and treatment. S. m. = Sinorhizobium meliloti and R. $l .=$ Rhizobium leguminosarum. 
accumulation of free SA that correlated with increased resistance against the powdery mildew fungus.

\section{DISCUSSION}

\section{Systemically induced resistance of $M$. truncatula and pea against the biotrophic powdery mildew fungus $E$. pisi coincides with rhizobia-induced priming \\ of SA accumulation and SA-related gene expression.}

Using agronomically important pea and $M$. truncatula, a legume model plant closely related to the widely used forage plant $M$. alfalfa, we found that a preestablished nodulation reduced penetration success of the adapted powdery mildew fungus $E$. pisi in M. truncatula and conidiation on pea leaves. (Figs. 1 and 2). Comparable nitrogen contents of symbiotic and control plants (Fig. $1 \mathrm{~A}$ and $2 \mathrm{~A}$ ) demonstrated that the observed protective systemic effect of the bacteria-root interaction on fungal leaf disease did not primarily depend on symbiotically increased overall nitrogen levels. However, nutritional benefits of the symbiosis that will not manifest in measurements of total plant nitrogen cannot be excluded to contribute to the observed effects.

The phytohormones JA and SA are important mediators of the well-studied systemically triggered resistance mechanisms ISR and SAR, respectively. Using M. truncatula reporter genes for both phytohormones (Fig. 3), we noted a trend for enhanced accumulation of SA-related rather than JA-dependent transcripts in leaves of nodulated E. pisi-inoculated plants (Fig. 4). The fact that the measured tendency for elevated mRNAs of SA-responsive genes was not robust enough to reflect statistical significance among the independent biological replicates on the one hand might rely on the variability of the two applied biological treatments (nodulation and powdery mildew inoculation). On the other hand, a transcriptome analysis after SA or JA treatment of M. truncatula would potentially reveal more strongly regulated reporter genes that might facilitate similar analyses in future studies.

The importance of SA-mediated defense in resistance of legumes against the biotrophic powdery mildews is congruent to findings in Arabidopsis, where SA signaling has been shown to play a pivotal role in defense against these fungi (Chandran et al. 2009, 2014; Dewdney et al. 2000; Ederli et al. 2015; Kuhn et al. 2016; Zhang et al. 2015). The involvement of SA-related gene expression in defense of $M$. truncatula against $E$. pisi is further substantiated by upregulation of $M$. truncatula homo$\operatorname{logs}$ of Arabidopsis SA-responsive marker genes upon E. pisi inoculation in different $M$. truncatula cultivars (Foster-Hartnett et al. 2007). Microarray experiments of penetration resistant (Jemalong A17), postpenetration resistant (A20) and highly susceptible (DZA315.16; used in this study) M. truncatula cultivars revealed equally increased transcript abundance of a common set of genes at $12 \mathrm{~h}$ post-fungal inoculation in response to E. pisi infection in resistant and susceptible cultivars, probably reflecting onset of basal resistance. These genes comprised $C H S$ and PR protein-encoding genes, including a $P R$-10 gene, a $P R$-1-like gene, $P R$-5-like thaumatin genes, and the hevein-like PR-4 Medtrlg080800 (TC101688) that we found to be induced by SA, upregulated upon $E$. pisi infection, and primed by nodulation (Figs. 3 and 4) (Foster-Hartnett et al. 2007). Samac et al. (2011) identified Medtrlg080800 (TC125088) among the most strongly upregulated genes in $M$. truncatula interacting with the leaf-infecting fungi $E$. pisi and Colletotrichum trifolii and the root-infecting oomycete Phytophthora medicaginis. The accumulation of the Medtrlg08080 mRNA in different cultivars and during infection with distinct pathogens, together with our expression data, suggests that, in M. truncatula, elicitation of SA-induced basal resistance-related gene expression is triggered by $E$. pisi inoculation and potentially elevated by nodulation.
Consistent with a tendency for induction of SA-related gene expression, SA accumulated in a statistically significant manner to higher quantities in leaves of nodulated plants at $1 \mathrm{dpi}$ with E. pisi in M. truncatula and at 7 dpi in pea compared with nonnodulated plants that had been infected or not with powdery mildew (Fig. 5). Strikingly, this coincided with the respective time points of enhanced penetration resistance $(1 \mathrm{dpi}$; M. truncatula) and reduced spore formation (7 dpi; pea) observed for both nodulated plant species (Figs. 1 and 2). This suggests that nodulation triggers priming for SA accumulation and SA-mediated defense, which is active against powdery mildew fungi. The measured basal levels of free SA are comparable with published data from $M$. truncatula and pea leaves (Jaulneau et al. 2010; Liu et al. 2006), respectively. Interestingly, although we could not find published data on pathogen-induced SA values for pea, the E. pisi-triggered SA accumulation of $M$. truncatula leaves is comparable with published data of plants (M. truncatula line $210 \mathrm{~F}$ ) inoculated with the hemibiotrophic fungus $C$. trifolii at $3 \mathrm{dpi}$, before the appearance of necrotic lesions (Jaulneau et al. 2010; Torregrosa et al. 2004). This finding suggests that SA-mediated signaling is involved in defense of $M$. truncatula against fungi during a biotrophic infection phase. Further research on the role of SA biosynthesis and signaling in nodulation-mediated powdery mildew resistance is required to confirm this hypothesis. A potential ortholog of ISOCHORISMATE SYNTHASE 1 (ICS1), the major player of SA biosynthesis in Arabidopsis, has been identified in M. truncatula (Zhang and Franken 2014). However, its functional characterization is missing, and it is not known whether, in $M$. truncatula, SA is primarily synthesized via the ICS pathway, as in Arabidopsis, or via the alternative phenylanaline ammonia lyase pathway, which strongly contributes to SA biosynthesis in soybean (Chen et al. 2009; Shine et al. 2016; Wildermuth et al. 2001).

\section{SA as a mediator of ISR.}

The observation that SA concentrations and SA-related gene expression are elevated during a root symbiont-triggered ISRlike effect against a shoot pathogen contrasts with the fact that JA is regarded as the major phytohormone mediating induced resistance during ISR (Pieterse et al. 1998, 2009, 2014; Van Wees et al. 2008). Conversely, priming of free SA levels or SAmediated gene expression occurs during SAR and is known to contribute to resistance of Arabidopsis against secondary infection (Jung et al. 2009). Still, JA is not the only critical defense hormone during ISR. Indeed, several reports confirm a contribution or requirement of SA-dependent signaling for ISRlike effects that partly also involves priming of SA-mediated gene expression (Cameron et al. 2013; Pieterse et al. 2014; Van Wees et al. 2008). Priming of SA-inducible $P R$ genes was reported during arbuscular mycorrhiza-triggered ISR of potato (Solanum tuberosum) against the hemibiotrophic oomycete $P$. infestans (Gallou et al. 2011) and during systemic resistance of Arabidopsis against Verticillium dahliae mediated by Paenibacillus alvei K165 (Tjamos et al. 2005). In the latter interaction, ISR further required intact SA biosynthesis and signaling (Tjamos et al. 2005). Likewise, Streptomyces sp. strain EN27-induced systemic resistance of Arabidopsis against F. oxysporum required SA (Conn et al. 2008). In addition, resistance against the hemibiotrophic bacterial pathogen Pseudomonas syringae pv. tomato and the insect pest Spodoptera exigua triggered by $P$. fluorescens SS101 also depends on SA but not on JA (van de Mortel et al. 2012). Furthermore, a role for SA in the induction of ISR of Arabidopsis and tomato against Botrytis cinerea has been described for several Trichoderma strains (Contreras-Cornejo et al. 2011; Martínez-Medina et al. 2013; Mathys et al. 2012). In conclusion, SA-dependent ISR and 
priming for SA-related gene expression has been reported for PGPF and PGPR and can mediate immunity against pathogens of different lifestyles and infection strategies.

\section{Nodulation modulates plant SA levels.}

When invading the plant, microbes must overcome the first layer of plant defense triggered by the recognition of MAMPs and referred to as MAMP-triggered immunity, which can render the plant resistant against invasion if not impeded by microbial effectors (Dangl and Jones 2001; Jones and Dangl 2006). MAMP-triggered responses include the accumulation of SA, which elicits SA-dependent defense upon microbial recognition (Tsuda et al. 2008). Legumes respond to the recognition of rhizobial MAMPs, similarly as to the recognition of pathogenic bacteria, by initiating an immune response (El Yahyaoui et al. 2004; Kouchi et al. 2004). However, this is quickly suppressed by nod factors that trigger the symbiotic program, eventually leading to nodule formation (Geurts and Bisseling 2002; Liang et al. 2013). As with biotrophic pathogens, high SA concentrations inhibit rhizobial infection (Ferguson and Mathesius 2014). Consequently, together with other MAMP responses, rhizobial nod factors mediate repression of transient SA accumulation that would otherwise inhibit root colonization (Blilou et al. 1999; Foo et al. 2014; Gutjahr and Paszkowski 2009; Martínez-Abarca et al. 1998; Stacey et al. 2006; Subramanian 2013; van Spronsen et al. 2003). Generally, successful establishment and maintenance of nodules is orchestrated by a fine-tuned interplay of distinct phytohormones (Ferguson and Mathesius 2014; Puppo et al. 2005). Therefore, it is not surprising that phytohormone levels are impacted by nodulation. However, whereas alterations in phytohormone homeostasis are well documented for root systems, only a few studies investigated phytohormone concentrations in shoots of nodulated plants and no reports on shoot levels of SA exist to our knowledge (Ferguson and Mathesius 2014; Puppo et al. 2005). Our results demonstrate that, while nodulation alone does not or only slightly increases SA values in the leaves of $M$. truncatula and pea plants, it primes the plants for accumulation of SA after powdery mildew challenge (Fig. 5).

\section{Nodulation differentially affects defense of M. truncatula and pea against $E$. pisi.}

As mentioned above, the protective effect of rhizobial symbiosis differed depending on the host plant: whereas, in M. truncatula, the fungal penetration success but not sporulation was impaired, E. pisi formed fewer conidia on pea leaves but showed unaltered penetration (Figs. 1 and 2). A discrepancy between impaired penetration and successful further fungal development, as observed for M. truncatula, has been reported also for distinct powdery mildew pathosystems. For example, oat powdery mildew (Blumeria graminis f. sp. avenae) penetration success on different oat (Avena sativa) genotypes does not necessarily correlate with development of secondary hyphae (Sánchez-Martín et al. 2011) and, in wild grapevine (Vitis rupestris), highly different penetration rates by E. necator can lead to very similar rates of sporulation (Barba et al. 2015).

This heterogeneous impact on penetration (M. truncatula) and sporulation (pea) that we observed (i) might reflect distinct degrees of adaptation of the fungus to the two different host species or (ii) may depend on the microsymbiont-host combinations used in our experiments.

(i) Different cultivars or accessions of both investigated hosts, M. truncatula and pea, showed different degrees of susceptibility against $E$. pisi, ranging from complete susceptibility through intermediate infection phenotypes to complete resistance. However, most pea and M. truncatula cultivars are susceptible to most E. pisi isolates (Fondevilla and Rubiales
2012; Prats et al. 2007; Sun et al. 2016). Moreover, the accessions we used (Pisum sativum Frisson and $M$. truncatula DZA315.16) are highly susceptible against E. pisi, indicating that the fungus is well adapted to both lines.

(ii) ISR-eliciting factors of PGPR comprise surface lipopolysaccharides, exopolysaccharides, flagella, biosurfactants, $\mathrm{N}$-acyl-homoserine lactones, $\mathrm{N}$-alkylated benzylamines, antibiotics, and siderophores, including bacterial SA (Beneduzi et al. 2012). Although rhizobia have not been reported to produce SA, rhizobial strains differ in their capacity to synthesize other siderophores, phytohormones such as gibberellic acid, distinct nod factors, lipopolysaccharides, exopolysaccharides, and effector proteins (Ghosh and Maiti 2016; Tatsukami and Ueda 2016; Wang et al. 2012). They also vary in their ability to fix nitrogen in different plant-rhizobial combinations (Schumpp and Deakin 2010). However, these characteristics are known to mainly affect host specificity, because rhizobial strains specifically colonize certain host plant groups (Laguerre et al. 2012; Wang et al. 2012). Due to their chitooligosaccharide backbone, nod factors closely resemble fungal chitooligomers (Dénarié and Cullimore 1993; Lerouge et al. 1990). MAMPs such as chitooligomers or bacterial flagellin are well-described elicitors of induced resistance (Zipfel et al. 2004) and can also act as a trigger for systemic resistance (Burketova et al. 2015). Therefore, it is conceivable that nod factors and further rhizobial molecules, similarly to the aforementioned PGPR factors (De Vleesschauwer and Höfte 2009; Shoresh et al. 2010), might act as inducers of ISR. This notion is supported by the study of Duzan et al. (2005), who found that purified nod factors of Bradyrhizobium japonicum 532C applied to soybean roots limited colony size of the powdery mildew fungus Microsphaera diffusa on leaves in a dose-dependent manner. Because nod factors and additional potential ISR elicitors such as lipopolysaccharides are also detectable in differentiating or differentiated bacteroids and root cells of nodules (Kannenberg et al. 1994; Skorupska et al. 2006; Timmers et al. 1998), they might contribute to the protective effect of established nodulation that we observed for powdery mildew resistance of Medicago truncatula and pea. Because these molecules differ depending on the rhizobial strain (Ghosh and Maiti 2016; Skorupska et al. 2006; Tatsukami and Ueda 2016; Wang et al. 2012), and also the plant receptors or targets of these factors differ in distinct hosts, it is possible that specific rhizobia-host combinations elicit differentially induced defense responses during penetration and postpenetration resistance. An example for this is the effect of PGPR lipopolysaccharides and flagellin on F. oxysporum. The respective purified molecules of Pseudomonas PGPR strains induced resistance in plants; however, the effect varied depending on the plant species to which these molecules were applied (Alabouvette et al. 2009, Bakker et al. 2007).

\section{Nodulation does not affect proliferation of the hemibiotrophic bacteria $X$. campestris pv. alfalfae.}

In contrast to the protective effect of nodulation against powdery mildew infection, nodulated $M$. truncatula plants remained fully susceptible against the hemibiotrophic bacterial pathogen $X$. campestris pv. alfalfae. Notably, the welldocumented protection of arbuscular mycorrhizal plants, which is mainly effective against necrotrophs, also systemically impairs infection by X. campestris pv. alfalfae (Liu et al. 2007). This seeming discrepancy between our data and published findings might either be related to the different inoculation methods used (syringe infiltration versus spray inoculation) or be attributed to distinct effects of rhizobia and arbuscular mycorrhiza-triggered ISR. Because syringe infiltration bypasses natural ingress into the apoplast, possibly enabling an 
earlier switch of the bacteria to a necrotrophic lifestyle, we chose spray inoculation to imitate a naturally occurring infection. The differential effectivity of nodulation-induced ISR against $E$. pisi and $X$. campestris pv. alfalfae might be due to the different modes of pathogenic infection and accommodation-penetration of epidermal cells (E. pisi) versus colonization of the intercellular spaces via stomata ( $X$. campestris pv. alfalfae) — or depend on distinct effects on pathogens with different lifestyles. Remarkably, bacterial disease progression quickly led to occurrence of chlorotic or necrotic leaves at 7 dpi, indicating that $X$. campestris pv. alfalfae rapidly changes lifestyle from biotrophy to necrotrophy and, therefore, JA- or ET-related ISR mechanisms of arbuscular mycorrhizal plants might be more effective against this pathogen.

\section{ISR: An additional advantage of nodulated legumes?}

In conclusion, we found that nodulation mediates increased resistance of two legumes against an adapted biotrophic powdery mildew parasite. Based on our experiments, we hypothesize that this observation potentially relies on priming of the shoot for SA-mediated defense. Interestingly, although the efficiency of nitrogen fixation in the symbiotic association between M. truncatula (Jemalong A17) and S. meliloti Sm2011 (or the closely related strain Sm1021) is suboptimal, the symbiosis is still persistent (Meade et al. 1982; Schumpp and Deakin 2010; Sulieman and Schulze 2010; Terpolilli et al. 2008). Remarkably, this phenomenon is common, because many legumes and rhizobia form inefficient nodules unable to provide the plant with sufficient nitrogen (Schumpp and Deakin 2010). In addition to regulatory difficulties to suppress inefficient nodulation (Schumpp and Deakin 2010), the beneficial effect on plant protection, despite a lacking nutritional advantage, might be one reason for the evolutionary advantage of the persistence of suboptimal nitrogen-fixing bacteria within nodules. Future investigations of the ability of rhizobial mutants defective in the installation of symbiosis and nitrogen fixation to facilitate ISR will answer the question of whether a functional symbiosis is required for the initiation of nodulationmediated systemic resistance.

\section{MATERIALS AND METHODS}

\section{Plant preparation and growth.}

Seeds of the E. pisi-susceptible (Foster-Hartnett et al. 2007) M. truncatula line DZA315.16 (HM005/L000734; kindly provided by Jean-Marie Prosperi at INRA-Montpellier) were scarified and surface sterilized with sulfuric acid and germinated as described by J. Garcia, D. G. Barker, and E.-P. Journet in the $M$. truncatula handbook. After 2 days of germination on inverted water agar $(9 \%)$ plates, nine seedlings were transferred to one Sterivent container (107 by 94 by $96 \mathrm{~mm}$; Duchefa, Haarlem, The Netherlands) containing sterile vermiculite that had been washed with water, supplemented with $250 \mathrm{ml}$ of nutritional solution per container $\left(1 \mathrm{mM} \mathrm{CaCl}_{2}, 100 \mu \mathrm{M} \mathrm{KCl}\right.$, $800 \mu \mathrm{M} \mathrm{MgSO}_{4}, 10 \mu \mathrm{M}$ Fe-EDTA, $35 \mu \mathrm{M} \mathrm{H}_{3} \mathrm{BO}_{3}, 0.3 \mu \mathrm{M}$ $\mathrm{CuSO}_{4}, 8 \mu \mathrm{M} \mathrm{ZnSO}_{4}, 9 \mu \mathrm{M} \mathrm{MnCl}_{2}, 0.5 \mu \mathrm{M} \mathrm{Na}_{2} \mathrm{MoO}_{4}, 20 \mu \mathrm{M}$ $\mathrm{KH}_{2} \mathrm{PO}_{4}$, and $20 \mu \mathrm{M} \mathrm{Na} \mathrm{HPO}_{4}$ ) and autoclaved. Each seedling was inoculated with $500 \mu \mathrm{l}$ of a suspension of $\beta$-glucuronidase (GUS) expressing S. meliloti Sm2011 (provided by J. Prell; RWTH Aachen University, Aachen, Germany) at an optical density at $600 \mathrm{~nm}(\mathrm{OD} 600)=0.1$ in sterile water that had been grown overnight in morpholineethanesulfonicacid- buffered $(10 \mu \mathrm{M} ; \mathrm{pH} 5.7)$ tryptone-yeast medium (per liter: $5 \mathrm{~g}$ of tryptone, $3 \mathrm{~g}$ of yeast extract, and $0.9 \mathrm{~g}$ of $\mathrm{CaCl}_{2}$ dihydrate) complemented with streptomycin at $50 \mathrm{mg}$ per liter. Seedlings that were not inoculated with rhizobia were supplemented with nutrient solution that additionally contained $7.5 \mathrm{mM} \mathrm{KNO}_{3}$.
Height, wet weight, and dry weight of $M$. truncatula plants were determined after 3 weeks.

Seeds of $P$. sativum 'Frisson' (JL2491/id\#25879; provided by M. Ambrose, Germplasm Resources Unit, John Innes Centre, Norwich, U.K.) were surface sterilized for $5 \mathrm{~min}$ with a $2 \%$ sodium hypochlorite solution, washed thoroughly with sterile water, and kept at $4^{\circ} \mathrm{C}$ in sterile water overnight. Four seeds were transferred into one container and inoculated with GUS expressing $R$. leguminosarum bv. viciae 3841 (kindly provided by Jürgen Prell; RWTH Aachen University) at $1 \mathrm{ml} / \mathrm{seed}$, as described for $M$. truncatula and $S$. meliloti. Seeds that were not inoculated with rhizobia were supplemented with $250 \mathrm{ml}$ of nutrient solution that additionally contained $5 \mathrm{mM} \mathrm{KNO}_{3}$. Pea and $M$. truncatula plants were grown in a daily cycle of $16 \mathrm{~h}$ of light $\left(23^{\circ} \mathrm{C}\right.$; approximately $\left.125 \mu \mathrm{mol} \mathrm{m} \mathrm{m}^{-2} \mathrm{~s}^{-1}\right)$ and $8 \mathrm{~h}$ of darkness $\left(20^{\circ} \mathrm{C}\right)$.

\section{E. pisi infection assays.}

For each independent experiment, 24 containers with nine M. truncatula or four pea plants each were prepared. In all, 12 of these containers were supplemented with $\mathrm{KNO}_{3}$ and 12 were treated with rhizobia. After 2 (pea) or 3 (M. truncatula) weeks, half of the plants of each treatment (six containers) were inoculated in an inoculation tower with $E$. pisi conidia that had been generated on susceptible pea plants. Leaves and roots were sampled at 1 (three containers) and 7 dpi (three containers) with E. pisi or after mock treatment. Roots were weighed and stained for GUS activity of rhizobia to evaluate nodule numbers per fresh weight. The sampled leaves were pooled and one fraction was frozen in liquid nitrogen and stored at $-80^{\circ} \mathrm{C}$ until further analysis of nitrogen content, transcript accumulation, or free SA content (depending on the experiment). Another fraction was used to analyze the percentage of successful penetration events $(1 \mathrm{dpi})$ and the sporulation (7 dpi). Penetration success was determined as described previously for Arabidopsis (Consonni et al. 2006) and asexual spore formation per gram $\mathrm{FW}$ was analyzed after collecting the conidia by thoroughly vortexing the leaves with water and counting in a Neubauer improved chamber (Weßling and Panstruga 2012).

\section{$X$. campestris pv. alfalfae infection assays.}

Eight containers with nine $M$. truncatula plants each were prepared for each independent experiment for inoculation with $X$. campestris pv. alfalfae. Of the eight containers, four were supplemented with $\mathrm{KNO}_{3}$ and four were inoculated with S. meliloti. X. campestris pv. alfalfae XA-1 (kindly provided by Steven Beer, Cornell University, Ithaca, NY, U.S.A.) was grown in Luria-Bertani (LB) medium and a suspension at $\mathrm{OD}_{600}=0.2$ was prepared in $10 \mathrm{mM} \mathrm{MgCl}$ and $0.04 \%$ Silwet. Three-weekold plants were spray inoculated with $X$. campestris pv. alfalfae 1 day after incubation of the containers in a closed tray to obtain high humidity and induce opening of stomata. Leaves of $X$. campestris pv. alfalfae-inoculated plants were sampled at three different time points: 0 (3 to $6 \mathrm{~h}$ after spraying), 3 , or 7 dpi. Sampling of the roots was performed as described for E. pisi-inoculated plants to determine the number of nodules per gram FW. Sampled leaves were combined into four to six technical replicates per time point, each of which consisted of two distinct leaves of two individual plants (four leaves in total). The leaf material was weighed, surface sterilized in $70 \%$ $\mathrm{EtOH}$, and washed twice with water. Afterward, the leaves were ground with a micropestle in a $1.5-\mathrm{ml}$ reaction tube in $500 \mu \mathrm{l}$ of $10 \mathrm{mM} \mathrm{MgCl}_{2}$. For each replicate, a dilution series $\left(10^{-1}\right.$ to $\left.10^{-5}\right)$ was prepared. Each dilution $(10 \mu \mathrm{l})$ was plated on an LB plate as technical triplicates. After 2.5 days at $28^{\circ} \mathrm{C}$, the colonies were counted and the CFU per gram of $\mathrm{FW}$ were calculated. 


\section{Phytohormone treatment of $M$. truncatula plants.}

Three-week-old $M$. truncatula plants (one container with six or more plants per treatment for each independent experiment, prepared as described above) were sprayed with $10 \mathrm{mM} \mathrm{SA}$, $1 \mathrm{mM}$ MeJA (both in aqueous solution), or water as a control treatment. In all cases, the $\mathrm{pH}$ was adjusted to 5.7 and $0.01 \%$ Tween-20 was added. The leaves were sampled at $12 \mathrm{~h}$ after the treatment, frozen in liquid nitrogen, and stored at $-80^{\circ} \mathrm{C}$.

\section{Evaluation of nitrogen content by gas chromatography.}

The nitrogen content of at least 18 (M. truncatula) or nine (pea) plants per time point and treatment as a percentage of dry weight was measured in 1- to 2-mg duplicates/sample of freezedried, ground leaf material encapsulated in tin boats, with a Purge and Trap gas chromatography unit equipped with a Vario EL III Element Analyzer (Elementar Analysensysteme, Hanau, Germany) (Dhaliwal et al. 2014). The instrument was calibrated against three samples of acetanilide, which was used as a standard (10.36\% nitrogen content).

\section{RNA extraction and}

quantitative reverse-transcription PCR.

Total RNA was isolated from frozen $M$. truncatula leaves of 18 or more plants per time point and was treated with the innuPREP Plant RNA Kit (Analytik Jena, Jena, Germany) according to the manufacturer's protocol. Quality of the RNA was checked spectrophotometrically and via agarose gel electrophoresis. RNA was digested with DNAse I and tested via PCR for absence of genomic DNA. cDNA was synthesized with the High-Capacity RNA-tocDNA Kit and oligodT primers according to the manufacturer's protocol (Thermo Fisher Scientific, Darmstadt, Germany). qPCR was performed with the Takyon No ROX SYBR Mastermix blue dTTP (Eurogentec, Köln, Germany) in 10- $\mu$ l reactions in a 384well-plate according to the manufacturer's two-step protocol, with melting curve analysis in a LightCycler 480 (Roche Diagnostics, Mannheim, Germany). Amplicons were sequenced to confirm the product identity. Transcript abundance was calculated with the $\triangle \Delta \mathrm{Ct}$ method (Livak and Schmittgen 2001) relative to the reference

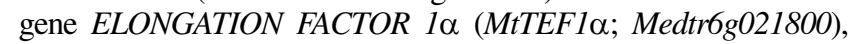
which is widely used as a $M$. truncatula reference gene during symbiosis and disease and showed great transcript stability upon JA treatment (Genevestigator database) (Hruz et al. 2008; Nyamsuren et al. 2003; Wulf et al. 2003).

\section{SA extraction and analysis}

\section{by high-performance liquid chromatography.}

Free SA was extracted from approximately $200 \mathrm{mg}$ of frozen leaf material (of at least 18 (M. truncatula) or (nine) pea pooled plants per time point and treatment) and quantified after a modified method of Meuwly and Métraux (1993) described by Kiefer and Slusarenko (2003). o-Anisic acid was used as an internal standard. In short, after extraction of ground leaves with methanol and partitioning against 50:50:0.5 ethyl acetatecyclohexane-isopropanol, the organic phases were separated and the solvent removed in a vacuum centrifuge. The residue was dissolved in $100 \mu \mathrm{l}$ of methanol per $100 \mathrm{mg}$ fresh weight of the primary plant material for further high-performance liquid chromatography (HPLC) analysis. The HPLC was conducted using water-acetic acid (950:50) as eluent $\mathrm{A}$ and methanol-acetic acid (950:50) as eluent $\mathrm{B}$ to perform the following gradient: $60 \% \mathrm{~A}$ (prerun), 53.5\% A (5.5 min), 40\% A (7 min), 35\% A (17 min), $10 \%$ A (20 min), 10\% A (25 min), 60\% A (26 min), and 60\% A (30 min). Under these conditions, $o$-anisic acid and SA were detected after 4.3 and $9.1 \mathrm{~min}$, respectively, using a fluorescence detector set at excitation wavelength $300 \mathrm{~nm}$ and emission wavelength $416 \mathrm{~nm}$. The HPLC-system (Jasco, Groß-Umstadt, Germany) consisted of a DG-2080-53
3-Line-Degasser, a LG-980-02 ternary gradient unit, a PU-980 intelligent HPLC pump, a CO-2060Plus Intelligent column thermostat, a AS-1555 intelligent sampler, a FP920 fluorescence detector, and an LC-Net II/ADC. The ChromPass Chromatography Data System, version 1.8.6.1, was used for control and analysis.

\section{Molecular phylogenetic analysis}

of SA- and JA-responsive marker genes.

BLASTP analysis against $M$. truncatula and Arabidopsis was performed with amino acid sequences encoded by Medtr8g018550, Medtr8g018690 (LOX genes), AtPR-1, and AtPR-4. BLAST hits with an $\mathrm{E}$ value $<10^{-4}$ were used for alignment by multiple sequence comparison by log-expectation (MUSCLE) (Edgar 2004). Molecular phylogenetic analysis was conducted in MEGA7 (Kumar et al. 2016). The evolutionary history was inferred by using the maximum-likelihood method based on the most suitable substitution model to correct for multiple changes at the same site during the evolutionary history of the sequences. The models used were the Whelan and Goldman model for AtPR-1 BLAST hits (Whelan and Goldman 2001), the JTT matrix-based model for AtPR-4 BLAST hits (Jones et al. 1992), and the Le and Gascuel model for LOXs (Le and Gascuel 2008). Alignment gaps were partially deleted. The bootstrap consensus tree inferred from 1,000 replicates was calculated (Felsenstein 1985). Branches corresponding to partitions reproduced in less than $50 \%$ bootstrap replicates were collapsed. Initial trees for the heuristic search were obtained automatically by applying Neighbor-Join and BioNJ algorithms to a matrix of pairwise distances estimated using a JTT model, and then selecting the topology with superior log-likelihood value. A discrete $\gamma$ distribution was used to model evolutionary rate differences among sites. All positions with less than $95 \%$ site coverage were eliminated.

\section{Statistical analysis and evaluation of priming.}

Statistical analysis of quantitative normally distributed experimental data was tested by Levene's test to confirm homogeneity of variance followed by one-way analysis of variance and Tukey's honestly significant difference post hoc test using R/Bioconductor (Gentleman et al. 2004). A Wilcoxon rank sum test was performed for nonnormally distributed data (spores per gram FW) that had been normalized to the respective control sample. Plants were defined as primed for a particular response if the response value of the rhizobium- $E$. pisi treatment was statistically significantly larger $(P \leq 0.05)$ than the response values of nitrate-E. pisi, rhizobium-mock, and nitrate-mock treatments. Box plots were generated with R/Bioconductor (Gentleman et al. 2004): center lines show the medians, box limits indicate the 25 th and 75 th percentiles as determined by $\mathrm{R}$ software, whiskers extend 1.5 times the interquartile range from the 25 th and 75 th percentiles, and outliers are represented by dots.

\section{ACKNOWLEDGMENTS}

We thank J. Prell for providing GUS-expressing $R$. leguminosarum and $S$ meliloti strains, J. Jahnke for helping with the nitrogen analysis, M. Ambrose for providing $P$. sativum .Frisson., S. Beer for providing X. campestris pv. alfalfae XA-1, and A. Reinstädler for maintenance of the E. pisi inoculum.

\section{AUTHOR-RECOMMENDED INTERNET RESOURCES}

M. truncatula genome resource: http://www.medicagogenome.org M. truncatula handbook: https://www.noble.org/medicagohandbook/

\section{LITERATURE CITED}

Alabouvette, C., Olivain, C., Migheli, Q., and Steinberg, C. 2009. Microbiological control of soil-borne phytopathogenic fungi with 
special emphasis on wilt-inducing Fusarium oxysporum. New Phytol. 184:529-544

Antico, C. J., Colon, C., Banks, T., and Ramonell, K. M. 2012. Insights into the role of jasmonic acid-mediated defenses against necrotrophic and biotrophic fungal pathogens. Front. Biol. 7:48-56.

Bakker, P. A. H. M., Pieterse, C. M. J., and van Loon, L. C. 2007. Induced systemic resistance by fluorescent Pseudomonas spp. Phytopathology 97:239-243.

Baldwin, I. T., Gorham, D., Schmelz, E. A., Lewandowski, C. A., and Lynds, G. Y. 1998. Allocation of nitrogen to an inducible defense and seed production in Nicotiana attenuata. Oecologia 115:541-552.

Barba, P., Cadle-Davidson, L., Galarneau, E., and Reisch, B. 2015. Vitis rupestris B38 Confers Isolate-Specific Quantitative Resistance to Penetration by Erysiphe necator. Phytopathology 105:1097-1103.

Beneduzi, A., Ambrosini, A., and Passaglia, L. M. P. 2012. Plant growthpromoting rhizobacteria (PGPR): Their potential as antagonists and biocontrol agents. Genet. Mol. Biol. 35:1044-1051.

Blilou, I., Ocampo, J. A., and García-Garrido, J. M. 1999. Resistance of pea roots to endomycorrhizal fungus or Rhizobium correlates with enhanced levels of endogenous salicylic acid. J. Exp. Bot. 50:1663-1668.

Bohlool, B. B., Ladha, J. K., Garrity, D. P., and George, T. 1992. Biological nitrogen-fixation for sustainable agriculture-A perspective. Plant Soil $141: 1-11$

Buonassisi, A., Copeman, R., Pepin, H., and Eaton, G. 1986. Effect of Rhizobium spp. on Fusarium solani f. sp. phaseoli. Can. J. Plant Pathol. 8:140-146.

Burketova, L., Trda, L., Ott, P. G., and Valentova, O. 2015. Bio-based resistance inducers for sustainable plant protection against pathogens. Biotechnol. Adv. 33:994-1004.

Cameron, D. D., Neal, A. L., van Wees, S. C. M., and Ton, J. 2013. Mycorrhiza-induced resistance: More than the sum of its parts? Trends Plant Sci. 18:539-545.

Chandran, D., Rickert, J., Huang, Y., Steinwand, M. A., Marr, S. K., and Wildermuth, M. C. 2014. Atypical E2F transcriptional repressor DEL1 acts at the intersection of plant growth and immunity by controlling the hormone salicylic acid. Cell Host Microbe 15:506-513.

Chandran, D., Tai, Y. C., Hather, G., Dewdney, J., Denoux, C., Burgess, D. G., Ausubel, F. M., Speed, T. P., and Wildermuth, M. C. 2009. Temporal global expression data reveal known and novel salicylateimpacted processes and regulators mediating powdery mildew growth and reproduction on Arabidopsis. Plant Physiol. 149:1435-1451.

Chen, Z., Zheng, Z., Huang, J., Lai, Z., and Fan, B. 2009. Biosynthesis of salicylic acid in plants. Plant Signal. Behav. 4:493-496.

Conn, V. M., Walker, A. R., and Franco, C. M. M. 2008. Endophytic actinobacteria induce defense pathways in Arabidopsis thaliana. Mol Plant-Microbe Interact. 21:208-218.

Conrath, U., Beckers, G. J. M., Flors, V., García-Agustín, P., Jakab, G., Mauch, F., Newman, M.-A., Pieterse, C. M. J., Poinssot, B., Pozo, M. J., Pugin, A., Schaffrath, U., Ton, J., Wendehenne, D., Zimmerli, L., and Mauch-Mani, B. (Prime-A-Plant Group). 2006. Priming: Getting ready for battle. Mol. Plant-Microbe Interact. 19:1062-1071

Conrath, U., Beckers, G. J. M., Langenbach, C. J. G., and Jaskiewicz, M. R 2015. Priming for enhanced defense. Annu. Rev. Phytopathol. 53: 97-119.

Consonni, C., Humphry, M. E., Hartmann, H. A., Livaja, M., Durner, J., Westphal, L., Vogel, J., Lipka, V., Kemmerling, B., Schulze-Lefert, P., Somerville, S. C., and Panstruga, R. 2006. Conserved requirement for a plant host cell protein in powdery mildew pathogenesis. Nat. Genet. 38:716-720.

Contreras-Cornejo, H. A., Macías-Rodríguez, L., Beltrán-Peña, E. Herrera-Estrella, A., and López-Bucio, J. 2011. Trichoderma-induced plant immunity likely involves both hormonal- and camalexindependent mechanisms in Arabidopsis thaliana and confers resistance against necrotrophic fungi Botrytis cinerea. Plant Signal. Behav. 6: 1554-1563.

Dakora, F. D. 2003. Defining new roles for plant and rhizobial molecules in sole and mixed plant cultures involving symbiotic legumes. New Phytol. 158:39-49.

Dangl, J. L., and Jones, J. D. G. 2001. Plant pathogens and integrated defence responses to infection. Nature 411:826-833.

Dénarié, J., and Cullimore, J. 1993. Lipo-oligosaccharide nodulation factors: A new class of signaling molecules mediating recognition and morphogenesis. Cell 74:951-954.

Desbrosses, G. J., and Stougaard, J. 2011. Root nodulation: A paradigm for how plant-microbe symbiosis influences host developmental pathways. Cell Host Microbe 10:348-358.

De Vleesschauwer, D., and Höfte, M. 2009. Rhizobacteria-induced systemic resistance. Pages 223-281 in: Advances in Botanical Research. Academic Press, New York.
Dewdney, J., Reuber, T. L., Wildermuth, M. C., Devoto, A., Cui, J., Stutius, L. M., Drummond, E. P., and Ausubel, F. M. 2000. Three unique mutants of Arabidopsis identify eds loci required for limiting growth of a biotrophic fungal pathogen. Plant J. 24:205-218.

Dhaliwal, G. S., Gupta, N., Kukal, S. S., and Meetpal, S. 2014 Standardization of automated Vario EL III CHNS analyzer for total carbon and nitrogen determination in plants. Commun. Soil Sci. Plant Anal. 45:1316-1324.

Dixon, R. A., Achnine, L., Kota, P., Liu, C.-J., Reddy, M. S. S., and Wang, L. 2002. The phenylpropanoid pathway and plant defence-A genomics perspective. Mol. Plant Pathol. 3:371-390.

Downie, J. A. 2014. Legume nodulation. Curr. Biol. 24:R184-R190.

Duzan, H. M., Mabood, F., Zhou, X., Souleimanov, A., and Smith, D. L. 2005. Nod factor induces soybean resistance to powdery mildew. Plant Physiol. Biochem. 43:1022-1030.

Ederli, L., Dawe, A., Pasqualini, S., Quaglia, M., Xiong, L., and Gehring, C. 2015. Arabidopsis flower specific defense gene expression patterns affect resistance to pathogens. Front. Plant Sci. 6:79.

Edgar, R. C. 2004. MUSCLE: Multiple sequence alignment with high accuracy and high throughput. Nucleic Acids Res. 32:1792-1797.

Ehteshamul-Haque, S., and Ghaffar, A. 1993. Use of rhizobia in the control of root rot diseases of sunflower, okra, soybean and mungbean. J. Phytopathol. 138:157-163

Ellis, C., Karafyllidis, I., and Turner, J. G. 2002a. Constitutive activation of jasmonate signaling in an Arabidopsis mutant correlates with enhanced resistance to Erysiphe cichoracearum, Pseudomonas syringae, and Myzus persicae. Mol. Plant-Microbe Interact. 15:1025-1030.

Ellis, C., Karafyllidis, I., Wasternack, C., and Turner, J. G. 2002b. The Arabidopsis mutant cev1 links cell wall signaling to jasmonate and ethylene responses. Plant Cell 14:1557-1566.

El Yahyaoui, F., Küster, H., Ben Amor, B., Hohnjec, N., Pühler, A., Becker, A., Gouzy, J., Vernié, T., Gough, C., Niebel, A., Godiard, L., and Gamas, P. 2004. Expression profiling in Medicago truncatula identifies more than 750 genes differentially expressed during nodulation, including many potential regulators of the symbiotic program. Plant Physiol. 136: 3159-3176.

Esnault, R., Buffard, D., Breda, C., Sallaud, C., el Turk, J., and Kondorosi, A. 1993. Pathological and molecular characterizations of alfalfa interactions with compatible and incompatible bacteria, Xanthomonas campestris pv. alfalfae and Pseudomonas syringae pv. pisi. Mol. PlantMicrobe Interact. 6:655-664.

Felsenstein, J. 1985. Confidence limits on phylogenies: An approach using the bootstrap. Evolution 39:783-791.

Ferguson, B. J., and Mathesius, U. 2014. Phytohormone regulation of legume-rhizobia interactions. J. Chem. Ecol. 40:770-790.

Fondevilla, S., and Rubiales, D. 2012. Powdery mildew control in pea. A review. Agron. Sustain. Dev. 32:401-409.

Foo, E., Ferguson, B. J., and Reid, J. B. 2014. Common and divergent roles of plant hormones in nodulation and arbuscular mycorrhizal symbioses. Plant Signal. Behav. 9:e29593.

Foster-Hartnett, D., Danesh, D., Peñuela, S., Sharopova, N., Endre, G. Vandenbosch, K. A., Young, N. D., and Samac, D. A. 2007. Molecular and cytological responses of Medicago truncatula to Erysiphe pisi. Mol Plant Pathol. 8:307-319.

Franken, P. 2012. The plant strengthening root endophyte Piriformospora indica: Potential application and the biology behind. Appl. Microbiol. Biotechnol. 96:1455-1464.

Fritz, M., Jakobsen, I., Lyngkjær, M. F., Thordal-Christensen, H., and PonsKühnemann, J. 2006. Arbuscular mycorrhiza reduces susceptibility of tomato to Alternaria solani. Mycorrhiza 16:413-419.

Fu, Z. Q., and Dong, X. 2013. Systemic acquired resistance: Turning local infection into global defense. Annu. Rev. Plant Biol. 64:839-863.

Gallou, A., Lucero Mosquera, H. P., Cranenbrouck, S., Suárez, J. P., and Declerck, S. 2011. Mycorrhiza induced resistance in potato plantlets challenged by Phytophthora infestans. Physiol. Mol. Plant Pathol. 76: 20-26.

Gao, Q.-M., Zhu, S., Kachroo, P., and Kachroo, A. 2015. Signal regulators of systemic acquired resistance. Front. Plant Sci. 6:228.

Gentleman, R. C., Carey, V. J., Bates, D. M., Bolstad, B., Dettling, M., Dudoit, S., Ellis, B., Gautier, L., Ge, Y., Gentry, J., Hornik, K., Hothorn, T., Huber, W., Iacus, S., Irizarry, R., Leisch, F., Li, C., Maechler, M., Rossini, A. J., Sawitzki, G., Smith, C., Smyth, G., Tierney, L., Yang, J. Y. H., and Zhang, J. 2004. Bioconductor: Open software development for computational biology and bioinformatics. Genome Biol. 5:R80.

Gernns, H., Alten, H., and Poehling, H.-M. 2001. Arbuscular mycorrhiza increased the activity of a biotrophic leaf pathogen-Is a compensation possible? Mycorrhiza 11:237-243. 
Geurts, R., and Bisseling, T. 2002. Rhizobium nod factor perception and signalling. Plant Cell 14:S239-S249.

Ghosh, P. K., and Maiti, T. K. 2016. Structure of extracellular polysaccharides (EPS) produced by rhizobia and their functions in legume-bacteria symbiosis-A review. Achiev. Life Sci. 10:136-143.

Glazebrook, J. 2005. Contrasting mechanisms of defense against biotrophic and necrotrophic pathogens. Annu. Rev. Phytopathol. 43:205-227.

Gray, E. J., and Smith, D. L. 2005. Intracellular and extracellular PGPR: Commonalities and distinctions in the plant-bacterium signaling processes. Soil Biol. Biochem. 37:395-412.

Gutjahr, C., and Paszkowski, U. 2009. Weights in the balance: Jasmonic acid and salicylic acid signaling in root-biotroph interactions. Mol. Plant-Microbe Interact. 22:763-772.

Hoffland, E., Pieterse, C. M. J., Bik, L., and van Pelt, J. A. 1995. Induced systemic resistance in radish is not associated with accumulation of pathogenesis-related proteins. Physiol. Mol. Plant Pathol. 46:309-320.

Hruz, T., Laule, O., Szabo, G., Wessendorp, F., Bleuler, S., Oertle, L., Widmayer, P., Gruissem, W., and Zimmermann, P. 2008. Genevestigator v3: A reference expression database for the meta-analysis of transcriptomes. Adv. Bioinf. 2008: Article 420747.

Huot, B., Yao, J., Montgomery, B. L., and He, S. Y. 2014. Growth-defense tradeoffs in plants: A balancing act to optimize fitness. Mol. Plant 7: 1267-1287.

Ishiga, Y., Uppalapati, S. R., Gill, U. S., Huhman, D., Tang, Y., and Mysore, K. S. 2015. Transcriptomic and metabolomic analyses identify a role for chlorophyll catabolism and phytoalexin during Medicago nonhost resistance against Asian soybean rust. Sci. Rep. 5: Article 13061.

Jaulneau, V., Cazaux, M., Wong Sak Hoi, J., Fournier, S., Esquerré-Tugayé, M.-T., Jacquet, C., and Dumas, B. 2010. Host and nonhost resistance in Medicago-Colletotrichum interactions. Mol. Plant-Microbe Interact. 23: 1107-1117.

Jones, D. T., Taylor, W. R., and Thornton, J. M. 1992. The rapid generation of mutation data matrices from protein sequences. Comput. Appl. Biosci. 8:275-282.

Jones, J. D. G., and Dangl, J. L. 2006. The plant immune system. Nature 444:323-329.

Jung, H. W., Tschaplinski, T. J., Wang, L., Glazebrook, J., and Greenberg, J. T. 2009. Priming in systemic plant immunity. Science 324:89-91.

Jung, S. C., Martínez-Medina, A., Lopez-Raez, J. A., and Pozo, M. J. 2012. Mycorrhiza-induced resistance and priming of plant defenses. J. Chem. Ecol. 38:651-664.

Kannenberg, E. L., Perotto, S., Bianciotto, V., Rathbun, E. A., and Brewin, N. J. 1994. Lipopolysaccharide epitope expression of Rhizobium bacteroids as revealed by in situ immunolabelling of pea root nodule sections. J. Bacteriol. 176:2021-2032.

Kaschuk, G., Leffelaar, P. A., Giller, K. E., Alberton, O., Hungria, M., and Kuyper, T. W. 2010. Responses of legumes to rhizobia and arbuscular mycorrhizal fungi: A meta-analysis of potential photosynthate limitation of symbioses. Soil Biol. Biochem. 42:125-127.

Kiefer, I. W., and Slusarenko, A. J. 2003. The pattern of systemic acquired resistance induction within the Arabidopsis rosette in relation to the pattern of translocation. Plant Physiol. 132:840-847.

Kloepper, J. W., Ryu, C.-M., and Zhang, S. 2004. Induced systemic resistance and promotion of plant growth by Bacillus spp. Phytopathology 94:1259-1266.

Kouchi, H., Shimomura, K., Hata, S., Hirota, A., Wu, G.-J., Kumagai, H., Tajima, S., Suganuma, N., Suzuki, A., Aoki, T., Hayashi, M., Yokoyama, T., Ohyama, T., Asamizu, E., Kuwata, C., Shibata, D., and Tabata, S. 2004. Large-scale analysis of gene expression profiles during early stages of root nodule formation in a model legume, Lotus japonicus. DNA Res. 11:263-274.

Kuhn, H., Kwaaitaal, M., Kusch, S., Acevedo-Garcia, J., Wu, H. and Panstruga, R. 2016. Biotrophy at its best: Novel findings and unsolved mysteries of the Arabidopsis-powdery mildew pathosystem. Arabidopsis Book 2016: Article e0184.

Kumar, S., Stecher, G., and Tamura, K. 2016. MEGA7: Molecular evolutionary genetics analysis version 7.0 for bigger datasets. Mol. Biol. Evol. 33:1870-1874.

Laguerre, G., Heulin-Gotty, K., Brunel, B., Klonowska, A., Le Quéré, A., Tillard, P., Prin, Y., Cleyet-Marel, J.-C., and Lepetit, M. 2012. Local and systemic N signaling are involved in Medicago truncatula preference for the most efficient Sinorhizobium symbiotic partners. New Phytol. 195: 437-449.

Le, S. Q., and Gascuel, O. 2008. An improved general amino acid replacement matrix. Mol. Biol. Evol. 25:1307-1320.

Lerouge, P., Roche, P., Faucher, C., Maillet, F., Truchet, G., Promé, J. C., and Dénarié, J. 1990. Symbiotic host-specificity of Rhizobium meliloti is determined by a sulphated and acylated glucosamine oligosaccharide signal. Nature 344:781-784.

Liang, Y., Cao, Y., Tanaka, K., Thibivilliers, S., Wan, J., Choi, J., Kang, Ch., Qiu, J., and Stacey, G. 2013. Nonlegumes respond to rhizobial Nod factors by suppressing the innate immune response. Science 341:1384-1387.

Lingua, G., D’Agostino, G., Massa, N., Antosiano, M., and Berta, G. 2002. Mycorrhiza-induced differential response to a yellows disease in tomato. Mycorrhiza 12:191-198.

Liu, H.-T., Liu, Y.-Y., Pan, Q.-H., Yang, H.-R., Zhan, J.-C., and Huang, W.-D. 2006. Novel interrelationship between salicylic acid, abscisic acid, and $\mathrm{PIP}_{2}$-specific phospholipase $\mathrm{C}$ in heat acclimation-induced thermotolerance in pea leaves. J. Exp. Bot. 57:3337-3347.

Liu, J., Maldonado-Mendoza, I., Lopez-Meyer, M., Cheung, F., Town, C. D., and Harrison, M. J. 2007. Arbuscular mycorrhizal symbiosis is accompanied by local and systemic alterations in gene expression and an increase in disease resistance in the shoots. Plant J. 50:529-544.

Livak, K. J., and Schmittgen, T. D. 2001. Analysis of relative gene expression data using real-time quantitative PCR and the $2^{-\Delta \Delta C T}$ method. Methods 25:402-408.

Loake, G., and Grant, M. 2007. Salicylic acid in plant defence-The players and protagonists. Curr. Opin. Plant Biol. 10:466-472.

Lorenzo, O., Chico, J. M., Sánchez-Serrano, J. J., and Solano, R. 2004. JASMONATE-INSENSITIVE1 encodes a MYC transcription factor essential to discriminate between different jasmonate-regulated defense responses in Arabidopsis. Plant Cell 16:1938-1950.

Maharjan, A., Bhatta, B., Acharya, R. P., G. C., S., and Shrestha, S. 2015. Efficacy assessment of treatment methods against powdery mildew disease of pea (Pisum sativum L.) caused by Erysiphe pisi var. pisi. World J. Agric. Res. 3:185-191.

Malamy, J., Carr, J. P., Klessig, D. F., and Raskin, I. 1990. Salicylic acid: A likely endogenous signal in the resistance response of tobacco to viral infection. Science 250:1002-1004.

Martínez-Abarca, F., Herrera-Cervera, J. A., Bueno, P., Sanjuan, J., Bisseling, T., and Olivares, J. 1998. Involvement of salicylic acid in the establishment of the Rhizobium meliloti-alfalfa symbiosis. Mol. Plant-Microbe Interact. 11:153-155.

Martínez-Medina, A., Fernández, I., Sánchez-Guzmán, M. J., Jung, S. C., Pascual, J. A., and Pozo, M. J. 2013. Deciphering the hormonal signalling network behind the systemic resistance induced by Trichoderma harzianum in tomato. Front. Plant Sci. 4:206.

Mathys, J., De Cremer, K., Timmermans, P., Van Kerckhove, S., Lievens, B., Vanhaecke, M., Cammue, B. P., and De Coninck, B. 2012. Genomewide characterization of ISR induced in Arabidopsis thaliana by Trichoderma hamatum T382 against Botrytis cinerea infection. Front. Plant Sci. 3:108.

Mauch-Mani, B., Baccelli, I., Luna, E., and Flors, V. 2017. Defense priming: An adaptive part of induced resistance. Annu. Rev. Plant Biol. 68:485-512.

Meade, H. M., Long, S. R., Ruvkun, G. B., Brown, S. E., and Ausubel, F. M. 1982. Physical and genetic characterization of symbiotic and auxotrophic mutants of Rhizobium meliloti induced by transposon Tn5 mutagenesis. J. Bacteriol. 149:114-122.

Meuwly, P., and Métraux, J. P. 1993. Ortho-anisic acid as internal standard for the simultaneous quantitation of salicylic acid and its putative biosynthetic precursors in cucumber leaves. Anal. Biochem. 214: 500-505.

Miransari, M. 2010. Contribution of arbuscular mycorrhizal symbiosis to plant growth under different types of soil stress. Plant Biol. (Berlin, Ger.) 12:563-569.

Müller, D. B., Vogel, C., Bai, Y., and Vorholt, J. A. 2016. The plant microbiota: Systems-level insights and perspectives. Annu. Rev. Genet. 50:211-234.

Nalam, V. J., Alam, S., Keereetaweep, J., Venables, B., Burdan, D., Lee, H., Trick, H. N., Sarowar, S., Makandar, R., and Shah, J. 2015. Facilitation of Fusarium graminearum infection by 9-lipoxygenases in Arabidopsis and wheat. Mol. Plant-Microbe Interact. 28:1142-1152.

Naoumkina, M., Farag, M. A., Sumner, L. W., Tang, Y., Liu, C.-J., and Dixon, R. A. 2007. Different mechanisms for phytoalexin induction by pathogen and wound signals in Medicago truncatula. Proc. Natl. Acad. Sci. U.S.A. 104:17909-17915.

Návarová, H., Bernsdorff, F., Döring, A.-C., and Zeier, J. 2012. Pipecolic acid, an endogenous mediator of defense amplification and priming, is a critical regulator of inducible plant immunity. Plant Cell 24: 5123-5141

Nyamsuren, O., Colditz, F., Rosendahl, S., Tamasloukht, M., Bekel, T. Meyer, F., Küster, H., Franken, P., and Krajinski, F. 2003. Transcriptional profiling of Medicago truncatula roots after infection with Aphanomyces 
euteiches (oomycota) identifies novel genes upregulated during this pathogenic interaction. Physiol. Mol. Plant Pathol. 63:17-26.

Paiva, N. L., Oommen, A., Harrison, M. J., and Dixon, R. A. 1994. Regulation of isoflavonoid metabolism in alfalfa. Plant Cell Tissue Organ Cult. 38:213-220.

Panstruga, R., and Kuhn, H. 2019. Mutual interplay between phytopathogenic powdery mildew fungi and other microorganisms. Mol. Plant Pathol. 20:463-470.

Pieterse, C. M. J Leon-Reyes, A., Van der Ent, S., and Van Wees, S. C. M 2009. Networking by small-molecule hormones in plant immunity. Nat. Chem. Biol. 5:308-316.

Pieterse, C. M. J., Van Pelt, J. A., Ton, J., Parchmann, S., Mueller, M. J., Buchala, A. J., Métraux, J.-P., and Van Loon, L. C. 2000. Rhizobacteriamediated induced systemic resistance (ISR) in Arabidopsis requires sensitivity to jasmonate and ethylene but is not accompanied by an increase in their production. Physiol. Mol. Plant Pathol. 57:123-134.

Pieterse, C. M. J., van Wees, S. C. M., van Pelt, J. A., Knoester, M., Laan, R., Gerrits, H., Weisbeek, P. J., and van Loon, L. C. 1998. A novel signaling pathway controlling induced systemic resistance in Arabidopsis. Plant Cell 10:1571-1580.

Pieterse, C. M. J., Zamioudis, C., Berendsen, R. L., Weller, D. M., Van Wees, S. C., and Bakker, P. A. H. M. 2014. Induced systemic resistance by beneficial microbes. Annu. Rev. Phytopathol. 52:347-375.

Potter, S., Uknes, S., Lawton, K., Winter, A. M., Chandler, D., DiMaio, J., Novitzky, R., Ward, E., and Ryals, J. 1993. Regulation of a hevein-like gene in Arabidopsis. Mol. Plant-Microbe Interact. 6:680-685.

Pozo, M. J., and Azcón-Aguilar, C. 2007. Unraveling mycorrhiza-induced resistance. Curr. Opin. Plant Biol. 10:393-398.

Prats, E., Llamas, M. J., and Rubiales, D. 2007. Characterization of resistance mechanisms to Erysiphe pisi in Medicago truncatula. Phytopathology 97:1049-1053.

Puppo, A., Groten, K., Bastian, F., Carzaniga, R., Soussi, M., Lucas, M. M., de Felipe, M. R., Harrison, J., Vanacker, H., and Foyer, C. H. 2005. Legume nodule senescence: Roles for redox and hormone signalling in the orchestration of the natural aging process. New Phytol. 165:683-701.

Riker, A. J., Jones, F. R., and Davis, M. C. 1935. Bacterial leaf spot of alfalfa. J. Agric. Res. 51:177-182.

Ryals, J. A., Neuenschwander, U. H., Willits, M. G., Molina, A., Steiner, H. Y., and Hunt, M. D. 1996. Systemic acquired resistance. Plant Cell 8: 1809-1819.

Samac, D. A., Peñuela, S., Schnurr, J. A., Hunt, E. N., Foster-Hartnett, D. Vandenbosch, K. A., and Gantt, J. S. 2011. Expression of coordinately regulated defence response genes and analysis of their role in disease resistance in Medicago truncatula. Mol. Plant Pathol. 12:786-798.

Sánchez-Martín, J., Rubiales, D., and Prats, E. 2011. Resistance to powdery mildew (Blumeria graminis $\mathrm{f}$. sp. avenae) in oat seedlings and adult plants. Plant Pathol. 60:846-856.

Schumpp, O., and Deakin, W. J. 2010. How inefficient rhizobia prolong their existence within nodules. Trends Plant Sci. 15:189-195.

Shine, M. B., Yang, J. W., El-Habbak, M., Nagyabhyru, P., Fu, D. Q., Navarre, D., Ghabrial, S., Kachroo, P., and Kachroo, A. 2016. Cooperative functioning between phenylalanine ammonia lyase and isochorismate synthase activities contributes to salicylic acid biosynthesis in soybean. New Phytol. 212:627-636.

Shoresh, M., Harman, G. E., and Mastouri, F. 2010. Induced systemic resistance and plant responses to fungal biocontrol agents. Annu. Rev. Phytopathol. 48:21-43.

Skorupska, A., Janczarek, M., Marczak, M., Mazur, A., and Król, J. 2006. Rhizobial exopolysaccharides: Genetic control and symbiotic functions. Microb. Cell Fact. 5:7.

Sonnemann, I., Streicher, N. M., and Wolters, V. 2005. Root associated organisms modify the effectiveness of chemically induced resistance in barley. Soil Biol. Biochem. 37:1837-1842.

Stacey, G., McAlvin, C. B., Kim, S.-Y., Olivares, J., and Soto, M. J. 2006. Effects of endogenous salicylic acid on nodulation in the model legumes Lotus japonicus and Medicago truncatula. Plant Physiol. 141:1473-1481.

Stein, E., Molitor, A., Kogel, K.-H., and Waller, F. 2008. Systemic resistance in Arabidopsis conferred by the mycorrhizal fungus Piriformospora indica requires jasmonic acid signaling and the cytoplasmic function of NPR1. Plant Cell Physiol. 49:1747-1751.

Subramanian, S. 2013. Distinct hormone regulation of determinate and indeterminate nodule development in legumes. J. Plant Biochem. Physiol. 1:110.

Sulieman, S., and Schulze, J. 2010. The efficiency of nitrogen fixation of the model legume Medicago truncatula (Jemalong A17) is low compared to Medicago sativa. J. Plant Physiol. 167:683-692.
Sun, S., Deng, D., Wang, Z., Duan, C., Wu, X., Wang, X., Zong, X., and Zhu, Z. 2016. A novel erl allele and the development and validation of its functional marker for breeding pea (Pisum sativum L.) resistance to powdery mildew. Theor. Appl. Genet. 129:909-919.

Tatsukami, Y., and Ueda, M. 2016. Rhizobial gibberellin negatively regulates host nodule number. Sci. Rep. 6: Article 27998.

Terpolilli, J. J., O’Hara, G. W., Tiwari, R. P., Dilworth, M. J., and Howieson, J. G. 2008. The model legume Medicago truncatula A17 is poorly matched for N2 fixation with the sequenced microsymbiont Sinorhizobium meliloti 1021. New Phytol. 179:62-66.

Thomma, B. P. H. J., Penninckx, I. A. M. A., Broekaert, W. F., and Cammue, B. P. 2001. The complexity of disease signaling in Arabidopsis. Curr. Opin. Immunol. 13:63-68.

Timmers, A. C., Auriac, M. C., de Billy, F., and Truchet, G. 1998. Nod factor internalization and microtubular cytoskeleton changes occur concomitantly during nodule differentiation in alfalfa. Development 125:339-349.

Tjamos, S. E., Flemetakis, E., Paplomatas, E. J., and Katinakis, P. 2005 Induction of resistance to Verticillium dahliae in Arabidopsis thaliana by the biocontrol agent K-165 and pathogenesis-related proteins gene expression. Mol. Plant-Microbe Interact. 18:555-561.

Ton, J., van der Ent, S., van Hulten, M., Pozo, M., van Oosten, V., van Loon, L., Mauch-Mani, B., Turlings, T. C., and Pieterse, C. M. 2009. Priming as a mechanism behind induced resistance against pathogens, insects and abiotic stress. IOBC WPRS Bull. 44:3-13.

Ton, J., Van Pelt, J. A., Van Loon, L. C., and Pieterse, C. M. J. 2002 Differential effectiveness of salicylate-dependent and jasmonate/ ethylene-dependent induced resistance in Arabidopsis. Mol. PlantMicrobe Interact. 15:27-34.

Torregrosa, C., Cluzet, S., Fournier, J., Huguet, T., Gamas, P., Prospéri, J.-M., Esquerré-Tugayé, M.-T., Dumas, B., and Jacquet, C. 2004 Cytological, genetic, and molecular analysis to characterize compatible and incompatible interactions between Medicago truncatula and Colletotrichum trifolii. Mol. Plant-Microbe Interact. 17:909-920.

Tsuda, K., Sato, M., Glazebrook, J., Cohen, J. D., and Katagiri, F. 2008. Interplay between MAMP-triggered and SA-mediated defense responses. Plant J. 53:763-775.

Tu, J. C. 1978. Protection of soybean from severe Phytophthora root rot by Rhizobium. Physiol. Plant Pathol. 12:233-240.

Tu, J. C. 1979. Evidence of differential tolerance among some root rot fungi to rhizobial parasitism in vitro. Physiol. Plant Pathol. 14:171-177.

van Dam, N. M., and Baldwin, I. T. 1998. Costs of jasmonate-induced responses in plants competing for limited resources. Ecol. Lett. 1:30-33

van Dam, N. M., and Heil, M. 2011. Multitrophic interactions below and above ground: En route to the next level. J. Ecol. 99:77-88.

van de Mortel, J. E., de Vos, R. C. H., Dekkers, E., Pineda, A., Guillod, L., Bouwmeester, K., van Loon, J. J. A., Dicke, M., and Raaijmakers, J. M. 2012. Metabolic and transcriptomic changes induced in Arabidopsis by the rhizobacterium Pseudomonas fluorescens SS101. Plant Physiol. 160: 2173-2188.

Van Loon, L. C., and Bakker, P. A. H. M. 2006. Induced systemic resistance as a mechanism of disease suppression by rhizobacteria. Pages 39-66 in PGPR: Biocontrol and Biofertilization. Z. A. Siddiqui, ed. Springer Netherlands, Dordrecht, The Netherlands.

van Spronsen, P. C., Tak, T., Rood, A. M. M., van Brussel, A. A. N., Kijne, J. W., and Boot, K. J. M. 2003. Salicylic acid inhibits indeterminate-type nodulation but not determinate-type nodulation. Mol. Plant-Microbe Interact. 16:83-91.

van Wees, S. C. M., Luijendijk, M., Smoorenburg, I., van Loon, L. C., and Pieterse, C. M. J. 1999. Rhizobacteria-mediated induced systemic resistance (ISR) in Arabidopsis is not associated with a direct effect on expression of known defense-related genes but stimulates the expression of the jasmonate-inducible gene Atvsp upon challenge. Plant Mol. Biol. 41:537-549.

Van Wees, S. C. M., Van der Ent, S., and Pieterse, C. M. J. 2008. Plant immune responses triggered by beneficial microbes. Curr. Opin. Plant Biol. 11:443-448

Verhagen, B. W. M., Glazebrook, J., Zhu, T., Chang, H.-S., van Loon, L. C. and Pieterse, C. M. J. 2004. The transcriptome of rhizobacteria-induced systemic resistance in Arabidopsis. Mol. Plant-Microbe Interact. 17: 895-908.

Vernooij, B., Friedrich, L., Morse, A., Reist, R., Kolditz-Jawhar, R., Ward, E., Uknes, S., Kessmann, H., and Ryals, J. 1994. Salicylic acid is not the translocated signal responsible for inducing systemic acquired resistance but is required in signal transduction. Plant Cell 6:959-965.

Vicente, J., Cascón, T., Vicedo, B., García-Agustín, P., Hamberg, M., and Castresana, C. 2012. Role of 9-lipoxygenase and $\alpha$-dioxygenase 
oxylipin pathways as modulators of local and systemic defense. Mol. Plant 5:914-928.

Walters, D. R., Ratsep, J., and Havis, N. D. 2013. Controlling crop diseases using induced resistance: Challenges for the future. J. Exp. Bot. 64:1263-1280.

Wang, D., Yang, S., Tang, F., and Zhu, H. 2012. Symbiosis specificity in the legume: Rhizobial mutualism. Cell. Microbiol. 14:334-342.

Wasternack, C. 2007. Jasmonates: An update on biosynthesis, signal transduction and action in plant stress response, growth and development. Ann. Bot. 100:681-697.

Wasternack, C., and Hause, B. 2013. Jasmonates: Biosynthesis, perception, signal transduction and action in plant stress response, growth and development. An update to the 2007 review in Annals of Botany. Ann. Bot. 111:1021-1058.

Weßling, R., and Panstruga, R. 2012. Rapid quantification of plantpowdery mildew interactions by qPCR and conidiospore counts. Plant Methods 8:35.

Whelan, S., and Goldman, N. 2001. A general empirical model of protein evolution derived from multiple protein families using a maximumlikelihood approach. Mol. Biol. Evol. 18:691-699.

Wildermuth, M. C., Dewdney, J., Wu, G., and Ausubel, F. M. 2001. Isochorismate synthase is required to synthesize salicylic acid for plant defence. Nature 414:562-565.
Wulf, A., Manthey, K., Doll, J., Perlick, A. M., Linke, B., Bekel, T., Meyer, F., Franken, P., Küster, H., and Krajinski, F. 2003. Transcriptional changes in response to arbuscular mycorrhiza development in the model plant Medicago truncatula. Mol. Plant-Microbe Interact. 16:306-314.

Zamioudis, C., and Pieterse, C. M. J. 2012. Modulation of host immunity by beneficial microbes. Mol. Plant-Microbe Interact. 25:139-150.

Zhang, H., and Franken, P. 2014. Comparison of systemic and local interactions between the arbuscular mycorrhizal fungus Funneliformis mosseae and the root pathogen Aphanomyces euteiches in Medicago truncatula. Mycorrhiza 24:419-430.

Zhang, L.-L., Ma, X.-F., Zhou, B.-B., Zhao, J.-Q., Fan, J., Huang, F., Li, Y., and Wang, W.-M. 2015. EDS1-mediated basal defense and SA-signaling contribute to post-invasion resistance against tobacco powdery mildew in Arabidopsis. Physiol. Mol. Plant Pathol. 91:120-130.

Zimmerli, L., Stein, M., Lipka, V., Schulze-Lefert, P., and Somerville, S. 2004. Host and non-host pathogens elicit different jasmonate/ethylene responses in Arabidopsis. Plant J. 40:633-646.

Zipfel, C., and Oldroyd, G. E. D. 2017. Plant signalling in symbiosis and immunity. Nature 543:328-336.

Zipfel, C., Robatzek, S., Navarro, L., Oakeley, E. J., Jones, J. D. G., Felix, G., and Boller, T. 2004. Bacterial disease resistance in Arabidopsis through flagellin perception. Nature 428:764-767. 